Portland State University

PDXScholar

Dissertations and Theses

Dissertations and Theses

1980

\title{
Age and the Comprehension of Spatial Adjectives
}

Barbara Ann Cassidy

Portland State University

Follow this and additional works at: https://pdxscholar.library.pdx.edu/open_access_etds

Part of the English Language and Literature Commons, and the Speech Pathology and Audiology Commons

Let us know how access to this document benefits you.

\section{Recommended Citation}

Cassidy, Barbara Ann, "Age and the Comprehension of Spatial Adjectives" (1980). Dissertations and Theses. Paper 2965.

https://doi.org/10.15760/etd.2960

This Thesis is brought to you for free and open access. It has been accepted for inclusion in Dissertations and Theses by an authorized administrator of PDXScholar. Please contact us if we can make this document more accessible: pdxscholar@pdx.edu. 
AN ABSTRACT OF THE THESIS OF Barbara Ann Cassidy for the Master of Science in Speech Communication, with an emphasis in Speech Pathology/ Audiology, presented May 8, 1980.

Title: Age and the Comprehension of Spatial Adjectives.

APPROVED BY MEMBERS OF THE THESIS COMMITTEE:
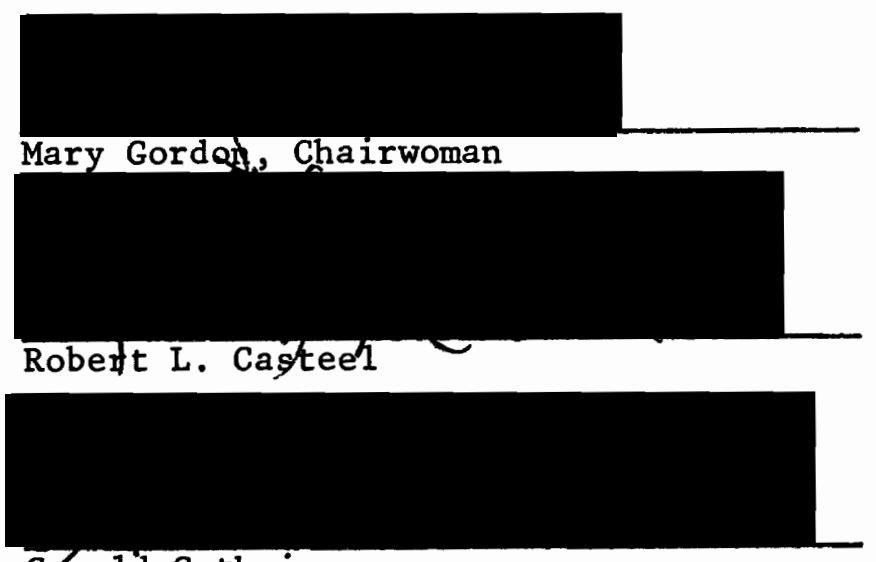

Gerald Guthrie

There has been considerable interest in the child's acquisition of spatial adjectives. However, few studies have investigated the significance of age on the child's comprehension of spatial adjectives in their polar (e.g., wide-narrow), comparative (e.g., wider-narrower) and superlative (e.g., widest-narrowest) forms.

The purpose of this study was to determine the significance of chronological age on the comprehension of spatial adjectives in children. Specifically, the investigation set out to determine the age levels at which children comprehend the polar forms of various spatial 
adjectives and to determine the difference in age levels of comprehension of unmarked versus marked adjective forms. Seventy children between the ages of two years, \pm 2 months and eight years, +2 months, selected on the basis of chronological age, normal receptive vocabulary recognition and normal hearing, participated as subjects.

The results showed a positive relationship between age of the children and their ability to receptively identify spatial adjectives. Each age group through the seven year olds identified a progressively higher percentage of spatial adjectives. The results also suggest overall insignificant differences in the comprehension of unmarked versus marked adjective forms with the exception of three year old subjects. 
AGE AND THE COMPREHENSION OF

SPATIAL ADJECTIVES

by

BARBARA ANN CASSIDY

A thesis submitted in partial fulfillment of the requirements for the degree of

MASTER OF SCIENCE IN SPEECH COMMUNICATION:

with an emphasis in

SPEECH PATHOLOGY/AUDIOLOGY

Portland State University

1980 
TO THE OFFICE OF GRADUATE STUDIES AND RESEARCH:

The members of the Committee approve the thesis of Barbara Ann Cassidy presented May 8, 1980.

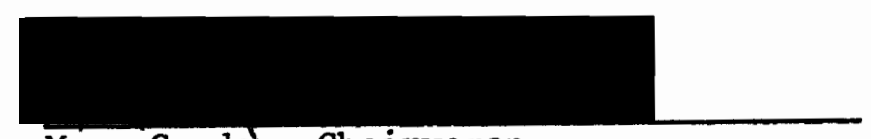

Mary Gorden, Chairwoman

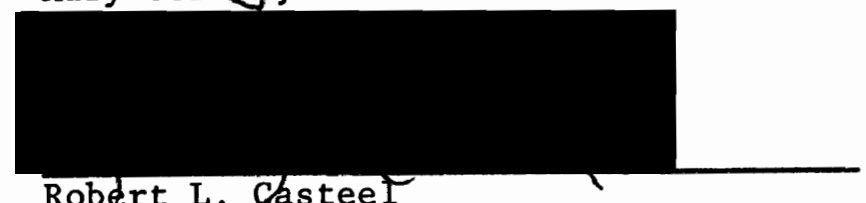

Robert L. CasteeI

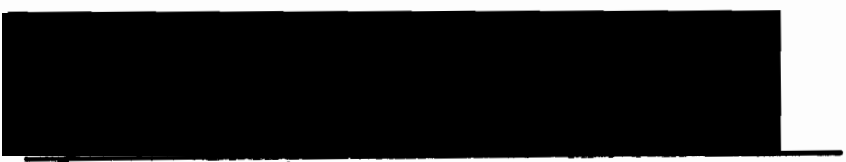

Gerald Guthrie

APPROVED :
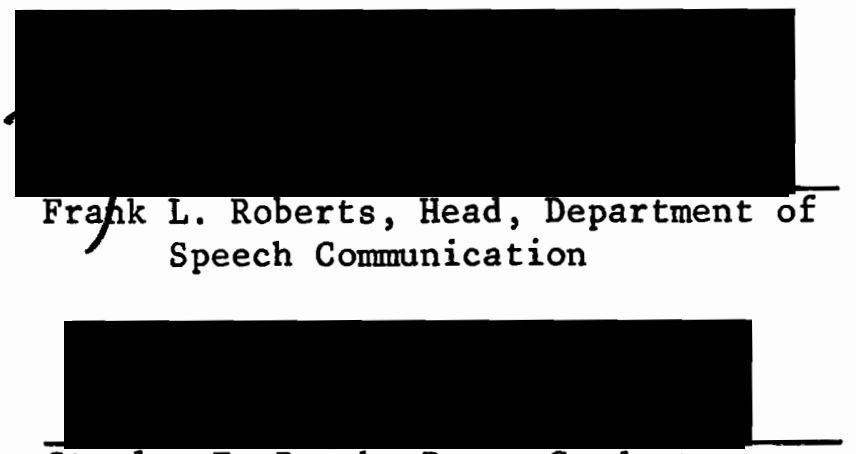

Stanley E. Rauch, Dean, Graduate Studies and Research 


\section{ACKNOWLEDGMENTS}

I express my sincere appreciation to those individuals who directly and indirectly helped make this investigation a success. I am especially grateful to Mary Gordon, my advisor and thesis director, who unselfishly devoted countless hours to advise, direct and encourage me as I worked my way through the many phases of this study. Her willingness to help and her continual availability made my task an easy one. Thank you, Mary. To Dr. Robert Casteel I extend thanks for serving on my committee and for seeing things from still another perspective. His suggestions allowed for a more logical presentation of material and spared me many hours of potential floundering. I also appreciate the comments offered by Dr. Gerald Guthrie and thank him for his remarkable ability to put a nervous orals candidate at ease.

Thank you to George Kent, a "numbers" person, for conducting and patiently explaining the statistical analysis of the data to a "words" person. I also thank my supervisor, James G. Juett, for allowing me the use of a typewriter at work nearly every week-end for the past two years. It saved me immeasurable time and was extraordinarily generous of him. Thanks also to Georgie Hustead, Barbara Kaplan, Kerry Lewis and Ann Laskey for providing words of encouragement and faith in me when they were needed most.

I wish to express sincere thanks to $\mathrm{Dr}$. Victor W. Doherty, Assistant Superintendent, Evaluation Department, who arranged for this investigation to be conducted in part in the Portland Public Schools. 
I also thank Chuck Nakvasil, the primary teachers, parents and students at Alameda School for their willingness to participate in this project. This study would have been impossible without the cooperation extended to me by Nancy Bemel, her staff and the parents and children of the Fruit and Flower Child Care Center. Margaret Browning and the staff at the Helen Gordon Child Development Center were also very accommodating and I express appreciation to them as well as the parents and children who were involved in the research. The combined efforts and enthusiasm of these individuals made my data collection an enjoyable experience.

My family and friends, far and near, have been extremely supportive throughout my educational process and for them I will be forever grateful. To Ear1, Rob, Jennie, Susie, Sara, Karen, Kathy, Nancy, Robin, Norma, Richard, Jenni, JKK, RWN, MAvB, Dee, Norton and Bill, I express thanks for kind words and at least feigned interest in my progress and research. Sincere thanks to my friend Mary Kendall for generously donating her time and artistic talents to draw the pictures included in the study. Thank you to my roommates JoAnne and Debbie, for support and understanding as I alternately complained and rejoiced over my efforts; life was infinitely more pleasant because of them. A special thank you to my friend Annie whose loyalty has never faltered and whose kindness has always endured.

Finally, I wish to thank my mother and father for providing me with the opportunity to enrich my life through education; for patient listening, moral support, unconditional love and the encouragement I needed to achieve my goals. It is to them that I dedicate this work. 
TABLE OF CONTENTS

Page

ACKNOWLEDGMENTS

LIST OF TABLES

vii

LIST OF FIGURES viii

\section{CHAPTER}

I INTRODUCTION AND STATEMENT OF PURPOSE ......... 1

Introduction .............. . 1

Statement of Purpose ............ 2

II REVIEW OF THE LITERATURE ............. 3

Theories of Semantic Development ....... 4

Unmarked and Marked Adjective Pairs ...... . 7

Unmarked Adjectives

Marked Adjectives

Acquisition of Adjectives . . . . . . . . 10

III METHODS AND PROCEDURES . . . . . . . . . . . 14

Subjects .................. 14

Instrumentation ............ . . 15

Experimental Procedures ........... 15

Data Scoring and Analysis.......... 16

IV RESULTS AND DISCUSSION . . . . . . . . . 17

Results............... . . 17

Discussion ............. 30 
CHAPTER

V SUMMARY AND IMPLICATIONS . . . . . . . . . . . . 34

Summary . . . . . . . . . . . . . . . 34

Implications . . . . . . . . . . . . 35

Research

Clinical

SELECTED BIBLIOGRAPHY . . . . . . . . . . • . . • • • • •

APPENDICES

A PERMISSION FORM . . . . . . . . . . . . . . . 40

B TEST STIMULI AND ORDER OF PRESENTATION . . . . . . . . 41

C TOTAL NUMBER CORRECT ADJECTIVES FOR EACH CHILD

AT EACH AGE LEVEL . . . . . . . . . . . . . 57 
LIST OF TABLES

TABLE

Page

I Group Means, Standard Deviations, Corresponding Percentages, and Number of Subjects Above and Below the Means on the Total Test... . . . . .

II Number of Children at Each Age Level That Correctly

Identified the Individual Spatial Adjectives . . . 20

III Group Means, Corresponding Percentages, and Number of Subjects Above and Below Means on Unmarked and Marked Items . . . . . . . . . . . . 24

IV Percentage of Subjects in Each Age Group Who Answered at Least 75 Percent of Unmarked and Marked Items Appropriately . . . . . . . . . .

$\mathrm{V}$ Analysis of Variance of Unmarked and Marked Adjectives for Two Year Olds . . . . . . . . . .

- VI Analysis of Variance of Unmarked and Marked Adjectives for Three Year Olds . . . . . . . . . .

VII Analysis of Variance of Unmarked and Marked Adjectives for Four Year Olds . . . . . . . . . .

VIII Analysis of Variance of Unmarked and Marked Adjectives for Five Year Olds . . . . . . . . . .

IX Analysis of Variance of Unmarked and Marked Adjectives for Six Year Olds . . . . . . . . . .

$\mathrm{X}$ Analysis of Variance of Unmarked and Marked Adjectives for Seven Year Olds . . . . . . . . .

XI Analysis of Variance of Unmarked and Marked Adjectives for Eight Year Olds . . . . . . . . . 


\section{LIST OF FIGURES}

1 Mean number of total test items answered appropriately by age group . . . . . . . . . 18

2 Minimum age levels at which 80 percent of all subjects appropriately identified each item . . . . 22

3 Comparison of mean number of items answered appropriately on unmarked and marked items by age group . . . . . . . . . . . . . . . .

4 Percentage of subjects in each age group who answered at least 75 percent ( 6 items) of unmarked and marked items appropriately 


\section{CHAPTER I}

\section{INTRODUCTION AND STATEMENT OF PURPOSE}

\section{Introduction}

As a child acquires semantic components of language, he eventually is able to classify words according to specific features and functions. As part of his development he learns to comprehend and express more specific and complex language structures, including the class of modifiers known as spatial adjectives, i.e., dimensional terms (e.g., wide-narrow, tall-short, thick-thin). The acquisition of spatial adjectives is a process which involves the development in the child's understanding of relational concepts and words (Donaldson and Wales, 1970; Klatzky, Clark and Macken, 1973).

There has been considerable interest in the child's acquisition of spatial adjectives. Studies have been conducted to investigate their use in terms of levels of abstraction (clark, 1973) and order of acquisition (Clark, 1972) and to determine the child's ability to express the comparative and superlative forms of adjectives (Berko, 1958). A review of the literature reveals few studies investigating the significance of age on the child's comprehension of spatial adjectives in the polar (e.g., wide-narrow), comparative (e.g., widernarrower) and superlative (e.g., widest-narrowest) forms. 


\section{Statement of Purpose}

The purpose of this study was to determine the significance of chronological age on the comprehension of spatial adjectives in children. The primary question posed was: At what age levels do children comprehend the polar forms of various spatial adjectives? A secondary question was: Is there a difference in the age levels of comprehension of unmarked versus marked adjective forms? 
CHAPTER II

REVIEW OF THE LITERATURE

An adjective is defined as a word which generally serves as the modifier of a noun to indicate the quality or extent of the noun or to differentiate one thing from another (Webster, 1971). Nelson (1976) identifies three functions of adjectives in adult language. She states they describe an aspect of a situation (e.g., She is a beautiful girl), determine which of several alternatives is being considered (e.g., He is a tal1 man) and sub-classify within a larger group (e.g., She lives in a brown house).

A child's use of adjectives is of interest because adjectives provide him with the ability to differentiate among objects and classes of objects based on the presence of specific stimuli (e.g., color, size, dimension), i.e., they allow him a linguistic means for generating new reference classes (Wiig and Seme1, 1976). Additionally, adjectives specify the properties which are essential to "concept formation, attention, memory and logical thought" (Nelson, 1976).

Adjectives are divided into various categories according to their primary features (e.g., color, size, dimension). One classification is spatial adjectives which are dimensional terms describing, relating to or occupying space (e.g., long-short, high-low, deep-shallow, widenarrow, thick-thin). 


\section{Theories of Semantic Development}

In order to understand the acquisition of spatial adjectives, it is necessary to be aware of the general acquisition of the semantic system and the comprehension of terms for space and time which stem from cognitive development. Several theories have been developed in the area of semantic acquisition. Bierwisch (1967) suggested all languages are based upon a specific set of universal characteristics which, upon combination, are transformed into semantic items. He believed there is a close relationship between language and cognitive development and proposed that semantic features cannot be different from language to language but are part of the general human capacity for language.

Another theory, suggested by McNeill (1970), stated the child initially acquires a "holophrastic dictionary" comprised of single words which carry the message of complete sentences (e.g., shoe may mean Daddy's shoe, There's a shoe, or The shoe is brown). As the child develops and his functional vocabulary increases, more sophistication allows the construction of syntactical, grammatical sentences. In addition, the child reorganizes his "dictionary" according to word meaning rather than sentence meaning. As a result, McNeill offered two possibilities for the growth of lexicon. His first hypothesis was that semantic development occurs "horizontally." In this stage only some semantic features of a word enter the "dictionary" resulting in word meanings which may differ from adult language. At that point, the child continues to add features for each word until horizontal development is complete.

The alternative to horizontal development is "vertical" 
development in which all the semantic features of a word, as well as the word itself, simultaneously enter the child's "dictionary."

McNeill explained that in vertical development, dictionary entries are initially "separated" and semantic features become unrelated. In this stage, words have the same semantic properties in the language of children and adults.

Another viewpoint is the Generalization Hypothesis presented by Anglin (1970) which implies that semantic development progresses from the concrete to the abstract in which the abstract relations include larger categories. The hypothesis is based on the belief that the young child's semantic knowledge increases with age, allowing generalizations to other categories. For example, at an early stage in development the child may learn "dog," "cow," "rose" and "oak," then group them into pairs and finally, categorize them as living entities.

In 1972 E. Clark presented the Semantic Feature Hypothesis to explain the acquisition of word meanings as the child develops language. The theory states that as a child learns language, he uses words with little understanding of their full adult meaning. The acquisition of semantic knowledge, then, consists of the addition of more features until the word more closely approximates that of adult language (Dale, 1976). The hypothesis predicts that general features are learned first and specific features are gradually added to differentiate one word from another (Eilers, Oller and Ellington, 1975).

Chomsky (1965, 1968) presents a fifth theory which states the child learns language because of some innate knowledge of the language which is biologically predetermined. This view is supported, in part, 
by Clark (1973) in that man is born with specific biological structures (e.g., eyes, ears) which lead him to develop "perceptual space." According to Clark, perceptual space is that conceptual awareness which is responsible for what is learned and how quickly. He states that a child cannot correctly apply the appropriate spatial terms of orientation without the presence of the concepts in perceptual space. In addition, he believes there are underlying linguistic concepts termed "linguistic space" which must be present in order for the child to be able to apply spatial terms to his perceptual space. Essentially, Clark contends the child knows a great deal about space and time, i.e., perceptual space, before he acquires the terms for designating the concepts, i.e., linguistic space. As a result of the above-described theories, the Correlation Hypothesis and Complexity Hypothesis have developed. These hypotheses are particularly relevant to the processes involved in the acquisition of spatial adjectives.

The Correlation Hypothesis (Clark, 1973) proposes there is a strong correspondence between perceptual and linguistic space. The theory implies that, for example, "verticality" is a dimension in (perceptual) space and is, as a result, a dimension in spatial expressions (linguistic space).

The Complexity Hypothesis (Clark, 1973) purports that specific conditions must exist before a word can be assigned to an event. The word "tall," for example, can be applied to a situation assuming the dimension is vertical. The Complexity Hypothesis which deals with perceptual events and spatial terms further states that, given two lexical items, the member with more possibilities for application will generally be acquired before the other member of the pair (e.g., tall 
before short). Clark (1973) explains that in "antonymous pairs, the positive member would be acquired before the negative member" because the positive member specifies a normal direction, and the negative member "specifies its direction by negating the assumed one." When considering spatial adjectives "positive" and "negative" members are referred to as "unmarked" and "marked" adjectives, respectively.

\section{Unmarked and Marked Adjective Pairs}

Spatial adjectives are asymmetrical in various ways and are often categorized in pairs; one adjective is typically designated as "unmarked" and the other as "marked" depending on specific characteristics of each member of the pair.

Unmarked Adjectives

In discussing unmarked and marked adjectives, "polarity" is frequently mentioned. Positive polarity, designated by a "+," refers to the presence of an attribute and represents unmarked adjectives (Bierwisch, 1967; Clark, 1973). Unmarked adjectives possess some specific quality, i.e., to be tall or wide is to have a "physical extension along a dimension," according to clark (1970).

Brewer and Lichtenstein (1974) consider "contextual neutralization" to be one of the most significant criteria in distinguishing between unmarked and marked linguistic forms. An unmarked adjective has the ability to remain neutral in questions and in the comparative form as compared to a marked adjective which always has a bias. One may ask, for example, "How tall is the boy?" as a request to place the boy along the tall-short continuum, making no assumption that the boy 
is tall rather than short (Clark, 1970; Donaldson and Wales, 1970;

Huttenlocher and Higgins, 1971; Carpenter, 1974). In the comparative sense, one may say, "The man is taller than the woman" implying that the man and the woman are both tall or suggesting that the man has a greater height than the woman without referring to the exact height of either (Clark, 1970).

Another criterion is that the name of the underlying semantic category is derived from the unmarked member of an adjective pair (Brewer and Lichtenstein, 1974; Carpenter, 1974) which refers to an area on a scale as well as the scale itself (Clark and Card, 1969; Clark, 1971; Ehri and Richardson, 1972). In other words, height is the name of the dimension established from the unmarked member, "high," in the high-low pair; width is the name of the dimension established from the unmarked member "wide," in the wide-narrow pair, and so on.

In addition, Brewer and Lichtenstein (1974) noted the unmarked member can be used quantitatively (e.g., The girl is five feet tall) and typically has a higher frequency of usage than the marked form.

Donaldson and Wales (1970) stated there is a superiority of performance in tasks involving the comprehension of unmarked adjectives because the positive, unmarked pole is generally the preferred member. Wales and Campbe11 (1970) and Carpenter (1974) concur by stating that people respond more rapidly and more correctly when verifying sentences containing an unmarked adjective rather than its marked counterpart. Klatzky, Clark, and Macken (1973) designed a study to differentiate between adult frequency and usage for asymmetry of adjectives. In order to eliminate the possibility that adult frequency of usage effects the learning of spatial terms, the children involved in the 
study were given a conceptual learning task in which nonsense syllables (CVC) were used to replace the English words for the positive and negative poles of size, height, length and thickness. The results revealed the syllables for the positive members of each dimensional pair required significantly fewer trials and produced significantly fewer errors. Palmero (1973) reported that children consistently understand positive terms before negative ones during learning.

\section{Marked Adjectives}

Marked adjectives are designated by a "-," (Bierwisch, 1967; Clark, 1973) and refer to the absence of an attribute (Vendler, 1968; Clark, 1970). That is, there are units of length and width, for example, but not of shortness and narrowness. Marked adjectives do not possess the ability to remain neutral in questions but, rather, imply previous judgment about a situation (Huttenlocher and Higgins, 1971; Streng, 1972). If, for example, one asked, "How short is the girl?" there is no doubt that the girl is short rather than tall; one simply wants to know how short. All neutrality has been removed (Vendler, 1968; Brewer and Lichtenstein, 1974). Another characteristic is that marked adjectives cannot be used quantitatively (e.g., The girl is five feet short). Marked adjectives are also thought to be more complex and less specific because they do not name a scale, only its negative pole (Ehri and Richardson, 1972). An additional distinction occurs when two adjective pairs are differentiated by an overt morphological marker (e.g., honest-dishonest). In that event, the member with the affix is the marked form (Brewer and Lichtenstein, 1974).

Clark and Card (1969) investigated the ability to recall unmarked 
and marked members of an adjective pair and found a significant tendency for marked adjectives to be mistakenly recalled as unmarked adjectives (e.g., recall of less rather than more in many cases.

In a study to investigate the child's acquisition of dimensional terms in children from four years to five years, five months of age, E. Clark (1972) used a word opposites task to elicit responses. The results provided no evidence to support Clark's (1973) Complexity Hypothesis. She found the children acquired the member with more possibilities for application (i.e., the unmarked member) at the same time they acquired the marked member of the adjective pairs tested.

Illerbrun (1975) conducted a study which compared the comprehension of spatial adjectives by children with normal language skills and children with deviant language development. The investigation included forty children ranging in age from four years, two months to five years, six months. The purpose was to determine if children find it easier to understand the unmarked or marked forms of spatial adjectives in the polar, comparative and superlative forms. Results indicated that children comprehend the marked member of an adjective pair at the same time as the unmarked member, supporting E. Clark's (1972) investigation.

\section{Acquisition of Adjectives}

Some researchers have investigated the acquisition of adjectives. Clark (1969, 1970, 1971) suggested three stages in the acquisition of antonym pairs. He indicated the initial development includes learning the nominal form in naming a dimension by use of the unmarked member of an adjective pair (e.g., The board is three feet long). In the second 
stage, the child learns to use the unmarked member of the pair in the contrastive sense (e.g., The board is long, meaning longer than is typical). Finally, the child applies the marked member of the pair in the contrastive sense (e.g., The board is short, meaning shorter than is typical). This review of the literature did not reveal research findings to support or deny Clark's proposed sequence in the acquisition of antonym pairs.

E. Clark's (1972) study of the acquisition of dimensional terms in children revealed a definite hierarchy in the acquisition of spatial adjectives in the previously discussed expressive word opposites task: long-short was followed by tall-short, then high-low, thick-thin, wide-narrow and deep-shallow.

The Manual for Evaluation of Speech, Language and Hearing Deve1opment in Children (Crippled Children's Division, 1958) states that at 42 months, children typically comprehend some adjectives (e.g., big, bad, old) and at 48 months they demonstrate consistent use of adjectives although they may use them incorrectly at times. At 72 months use of adjectives comprises about 12 percent of the total number of words used.

Berko (1958) conducted an investigation involving the elicitation of comparative and superlative endings of adjectives. She provided pictures to children four to seven years of age. The pictures depicted a specific attribute of a situation and, as the task progressed, the pictures portrayed more attributes for elicitation of the appropriate comparative and superlative adjective forms. When the child was unable to supply the comparative form, the examiner provided it in order to elicit the superlative form. Under that condition, 35 percent of the 
children supplied the superlative forms of the adjectives. Without the cue from the examiner, one child in the study responded appropriately. From the results of Berko's investigation, Wood (1976) concluded young children are not able to express comparative or superlative forms until they reach approximately six years of age. Illerbrun (1975) determined from results of his study that children had significantly more difficulty understanding the comparative form than the polar and superlative forms. Wood (1976) recommended instruction of adjective forms in the second and third grades to aid in the acquisition of such forms.

Similar to Wood, Entwisle (1966) concluded that antonym pairs are still being acquired in the second grade. Based on an investigation of children's word associations, she further suggested that between the ages of six and eight years, children are in the midst of forming adjective structures in order to categorize nouns according to their most obvious features. Entwisle also pointed out there is a substantial increase in the use of adjectives between kindergarten and third grade and a subsequent increase from the third to fifth grade.

Various diagnostic instruments for the evaluation of language functioning in children sample the comprehension of adjectives. None of the tests examined by this investigator provided more than three items pertaining to any form of adjectives, i.e., polar, comparative or superlative, and age levels for the comprehension of adjectives were not included. The tests examined included the Bankson Language Screening Test (Bankson, 1977), Test of Basic Concepts (Boehm, 1969), Test for Auditory Comprehension of Language (Carrow, 1973) and the Preschool Language Scale (Zimmerman, Steiner and Evatt, 1969).

The literature did not yield further information on the process 
or age of acquisition of adjective pairs in their polar, comparative or superlative forms. Research on the comprehension of spatial adjectives is necessary in order to aid the speech/language pathologist in dealing with language delayed and language disordered individuals. 


\section{CHAPTER III}

\section{METHODS AND PROCEDURES}

\section{Subjects}

This investigation included seventy children who were selected on thel basis of chronological age, normal vocabulary recognition and normal hearing. Ten children comprised each of seven age groups beginning at two years, \pm 2 months through eight years, \pm 2 months, at oneyear intervals. The subjects were selected with no preference to sex of the child from the Fruit and Flower Child Care Center, the Helen Gordon Child Development Center and Alameda Elementary School, all Portland, Oregon agencies.

Initially, parents of potential subjects were sent permission form letters explaining the nature and purpose of the study (Appendix A). Students with returned, signed permission forms were then screened for inclusion in the investigation.

Children with reported physical handicaps (such as cerebral palsy or uncorrected visual impairments which would interfere with the investigation) were excluded from the study. The Peabody Picture Vocabulary Test, Form A (Dunn, 1971) was administered to all subjects. Children with a receptive vocabulary age which was consistent with chronological age \pm 6 months participated in the investigation. Additionally, each child was required to demonstrate hearing acuity within normal limits by passing a hearing screening test. All hearing screening was 
performed at $20 \mathrm{dBHL}$ by the examiner at the time of initial subject contact. Each child meeting all screening criteria was included in the study.

\section{Instrumentation}

A portable Beltone 10D audiometer, serial number 51858 , was used to conduct the audiometric screening of the subjects in this investigation.

The Peabody Picture Vocabulary Test, Form A (Dunn, 1971) is an instrument designed to provide an estimate of a subject's verbal intelligence through the measurement of receptive vocabulary.

This investigator developed the Test for the Comprehension of Spatial Adjectives to determine the age levels at which children comprehend the polar forms of various spatial adjectives. The test materials consisted of $81 / 2 " \times 11^{\prime \prime}$ black and white drawings which were demonstrated through field testing to be representative of the lexical items being tested. The lexical items included "big," (vs. little), "little," "high," "low," "big,". (vs. sma11), "sma11," "tall," "short," (vs. tal1), "wide," "narrow," "long," "short," (vs. 1ong), "deep," "shallow," "thick" and "thin." The sequence of presentation was the same for each child. Illustrations of test stimuli are shown in Appendix B.

\section{Experimental Procedures}

Each subject was tested in a quiet, familiar room in his school. The researcher and the child sat across from each other with a small table between them. The researcher began each testing session with 
casual conversation for the purpose of putting the child at ease. The Peabody Picture Vocabulary Test, Form A (Dunn, 1971), was administered and hearing screening completed. If criteria were met on these two procedures, the researcher administered the Test for the Comprehension of Spatial Adjectives. All testing stimuli were placed on the floor by the researcher and were presented individually to the child. For example, when the researcher wanted to elicit a response for "big," three pictures were placed on the table. One picture was the target adjective being tested (e.g., big), another was the antonym member of the pair (e.g., little) and the third was a distractor (e.g., wide). The investigator gave the command, e.g., "Point to big."

\section{Data Scoring and Analysis}

A11 tests were administered and scored by the researcher. Each subject received one point for each correct response and a zero for each incorrect response. The total possible score was eighteen. Treatments-by-Subjects Designs (Bruning and Kintz, 1977) were performed to determine the statistical significance of differences between comprehension of unmarked versus marked test items. A descriptive approach was used to analyze the data concerning the age of comprehension of the adjectives, as well as the order of acquisition of the selected spatial adjectives, through tables, charts and graphs. 
CHAPTER IV

RESULTS AND DISCUSSION

$\underline{\text { Results }}$

The purpose of this study was to determine the significance of chronological age on the comprehension of spatial adjectives in children. The primary question posed was: At what age levels do children comprehend the polar forms of various spatial adjectives? A secondary question was: Is there a difference in the age levels of comprehension of unmarked versus marked adjective forms? Raw data appear in Appendix C.

As shown in Figure 1 and Table $I$, performance on the test generally improved with age. The mean number of items correctly identified increased from 2.1 (13 percent) at age two years, to 11.5 (72 percent) at four years. The mean scores continued to increase at a slower rate from 13.7 ( 86 percent) at five years to 14.5 (91 percent) at six years of age. A slight decrease was demonstrated between age seven and eight years, with means of 15.5 ( 97 percent) and 15.3 ( 96 percent), respectively.

Table II shows the mean scores for each age ranging from 2.1 to 15.5 out of a possible 18 points. The percentage of the adjectives responded to with 100 percent success at the various age levels ranges from 0 percent at the two year level to 75 percent at the eight year level. As shown in the table, three spatial adjectives, "thin," 


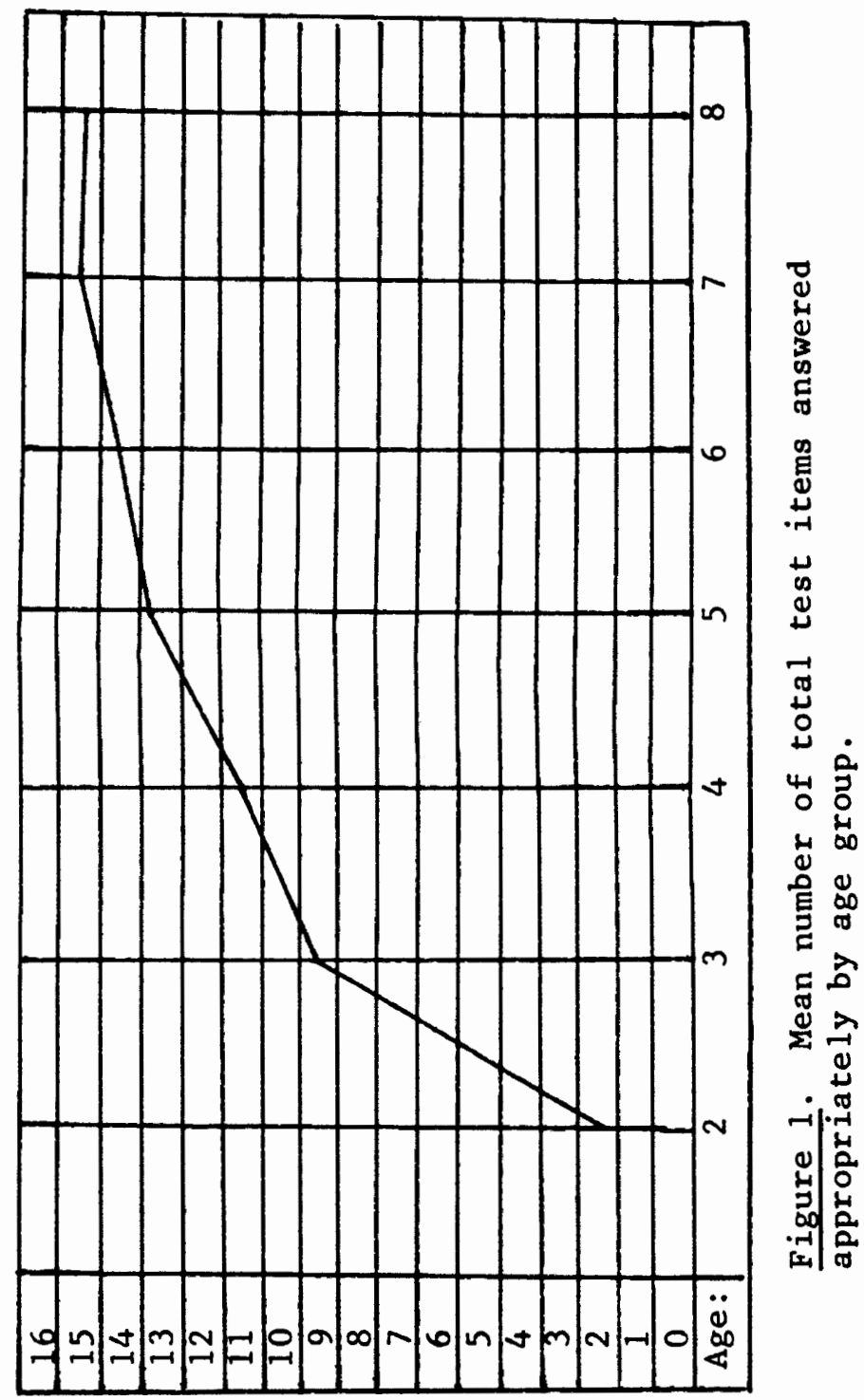

swə7I 7səL IE7OL fo xәqunN 
"narrow" and "thick were never correctly responded to by all subjects of any of the age groups.

Additionally, Table II indicates which adjectives were correctly identified by all children of each age group. All 10 children three years of age correctly identified "little." At four years of age all children correctly identified "little," "deep," "big," (vs. 1ittle), "big," (vs. sma11), and "low." All five year children correctly identified "short," "little," "high," "big," (vs. little), "big," (vs. sma11), "long," "wide," "low" and "sma11." At six years of age 10 out of 10 children correctly identified "short," (vs. tal1), "little," "high," "big," (vs. Iittle), "tal1," "big," (vs. sma11), "wide," "low" and "small." At seven years of age all children identified the following spatial adjectives correctly: "short," (vs. long), "short," (vs.

\section{TABLE I}

GROUP MEANS, STANDARD DEVIATIONS, CORRESPONDING PERCENTAGES, AND NUMBER OF SUBJECTS

ABOVE AND BELOW THE MEANS

ON THE TOTAL TEST

\begin{tabular}{|c|c|c|c|c|c|c|c|}
\hline Age & 2 & 3 & 4 & 5 & 6 & 7 & 8 \\
\hline Means & $\begin{array}{c}2.1 \\
(13 \%)\end{array}$ & $\begin{array}{c}9.7 \\
(61 \%)\end{array}$ & $\begin{array}{l}11.5 \\
(72 \%)\end{array}$ & $\begin{array}{l}13.7 \\
(86 \%)\end{array}$ & $\begin{array}{l}14.5 \\
(91 \%)\end{array}$ & $\begin{array}{l}15.5 \\
(97 \%)\end{array}$ & $\begin{array}{l}15.3 \\
(96 \%)\end{array}$ \\
\hline SD & .99 & 1.82 & 1.35 & 1.33 & .97 & .97 & .94 \\
\hline $\begin{array}{l}\text { \# of } S \\
\text { Above } \\
\text { Mean }\end{array}$ & 3 & 6 & 5 & 5 & 4 & 7 & 5 \\
\hline $\begin{array}{l}\text { \# of S } \\
\text { Below } \\
\text { Mean }\end{array}$ & 7 & 4 & 5 & 5 & 6 & 3 & 5 \\
\hline
\end{tabular}




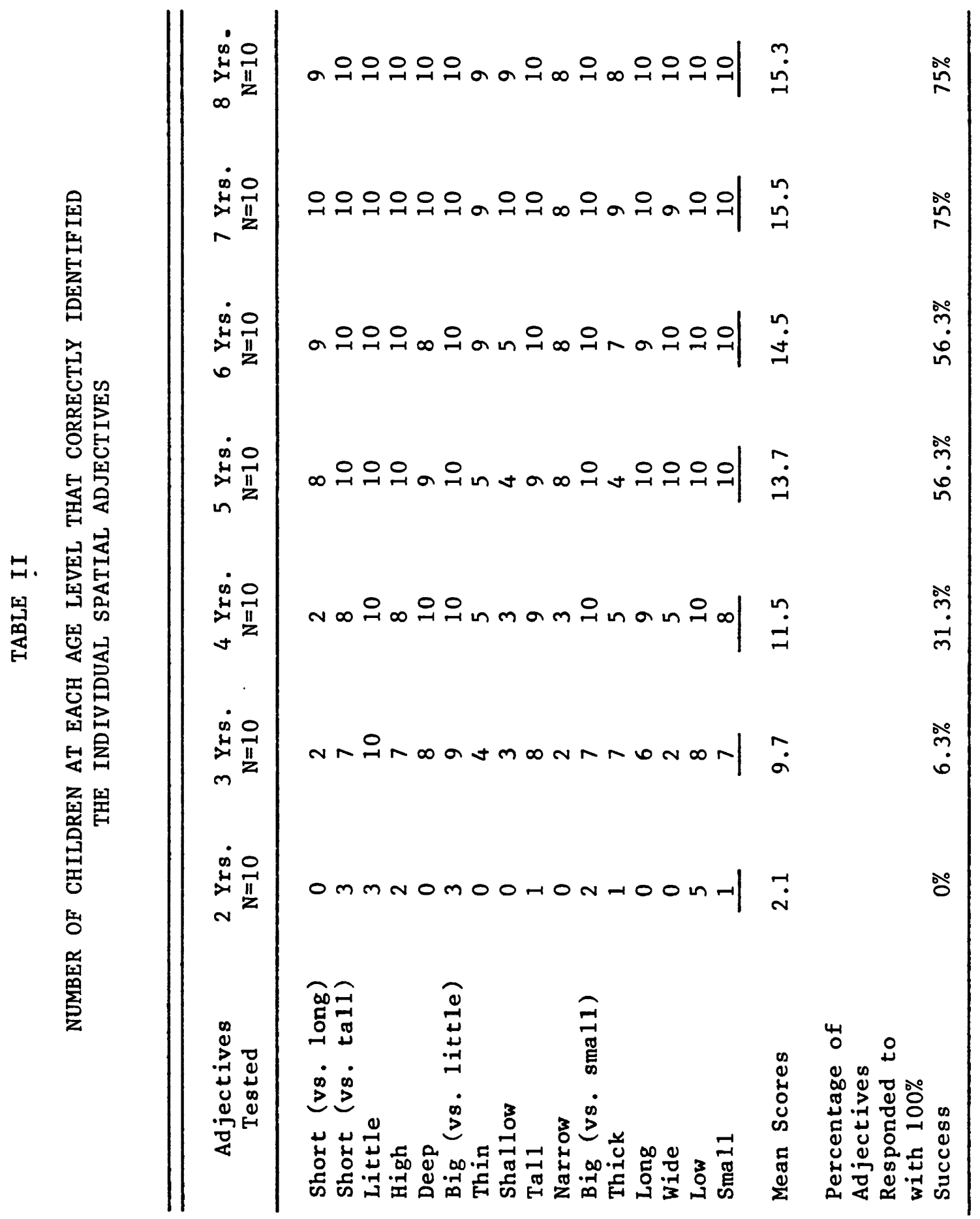


ta11), "little," "high," "deep," "big," (vs. 1ittle), "shallow," "ta11," "big," (vs. sma11), "long," "low" and "sma11." At eight years of age 10 out of 10 children identified the following spatial adjectives correctly: "short," (vs. tall), "little," "high," "deep," "big," (vs. little), "ta11," "big," (vs. sma11), "long," "wide," "low" and "sma 11."

Figure 2 demonstrates the minimum age level at which 80 percent or more of the subjects identified each spatial adjective. At age three, at least 80 percent of all subjects correctly identified "little," "deep," "big," (vs. little), "tall" and "low." At age four, "short," (vs. tal1), "high," "big," (vs. smal1), "long" and "small" were correctly identified. At five years of age, at least 80 percent correctly identified "short," (vs. long), "narrow" and "wide." At six years of age at least 80 percent of all subjects correctly identified "thin." At seven years of age "shallow" and "thick" were identified by 80 percent or more of all subjects.

In order to analyze the difference in the age levels of comprehension of unmarked and marked spatial adjectives, the data were divided into two groups: scores on the unmarked items and scores on the marked items (see Figure 3 and Table III). Upon visual inspection, the curve (see Figure 3 ) representing the mean number of unmarked items answered appropriately by each age group differed from the curve representing the mean number of marked items answered appropriately by each age group.

A comparison of the performance on unmarked items and marked items at each age group revealed higher mean scores on the unmarked items for six of the seven age groups (see Figure 3 and Table III). 


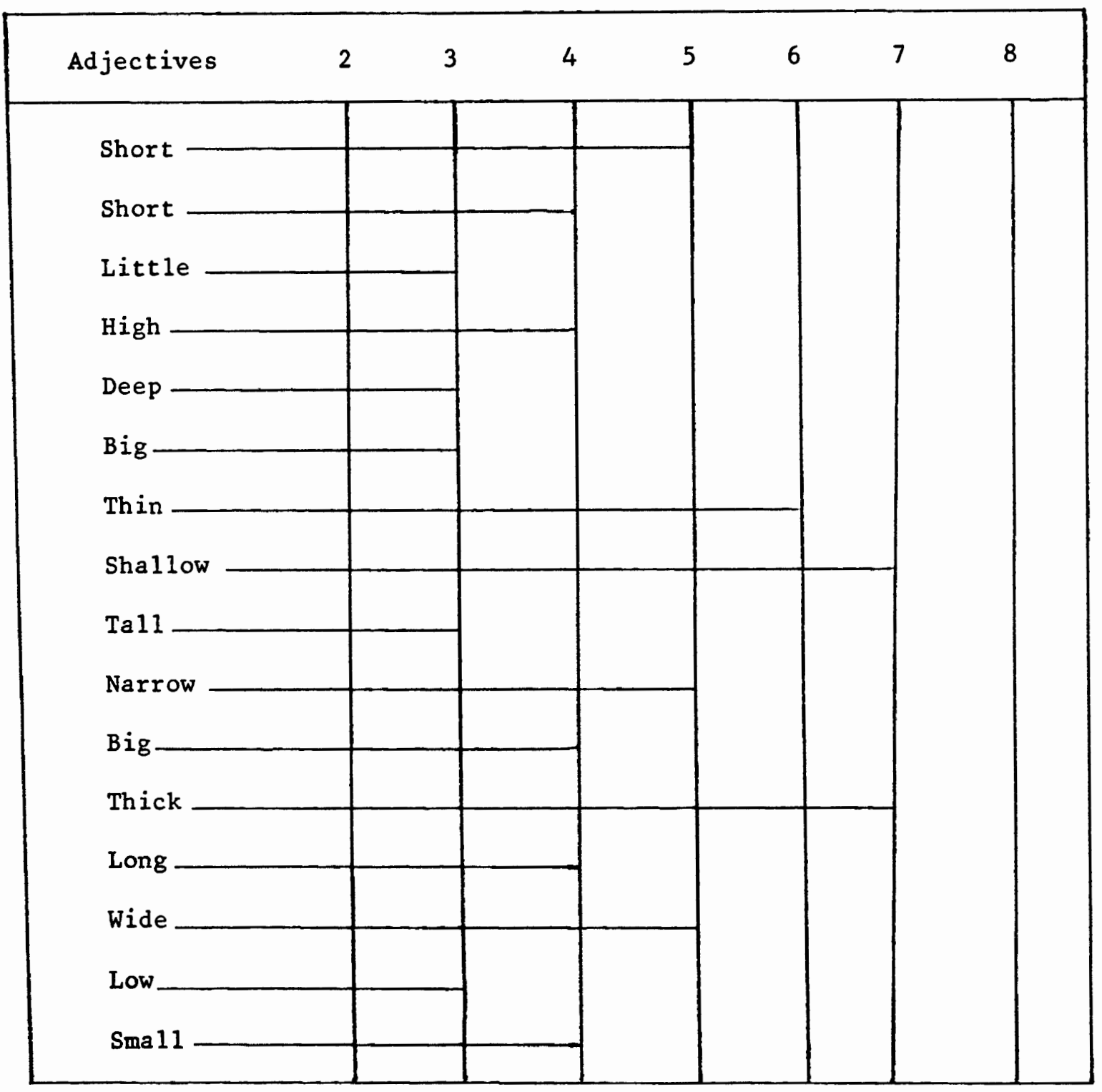

Figure 2. Minimum age levels at which 80 percent of all subjects appropriately identified each item. 


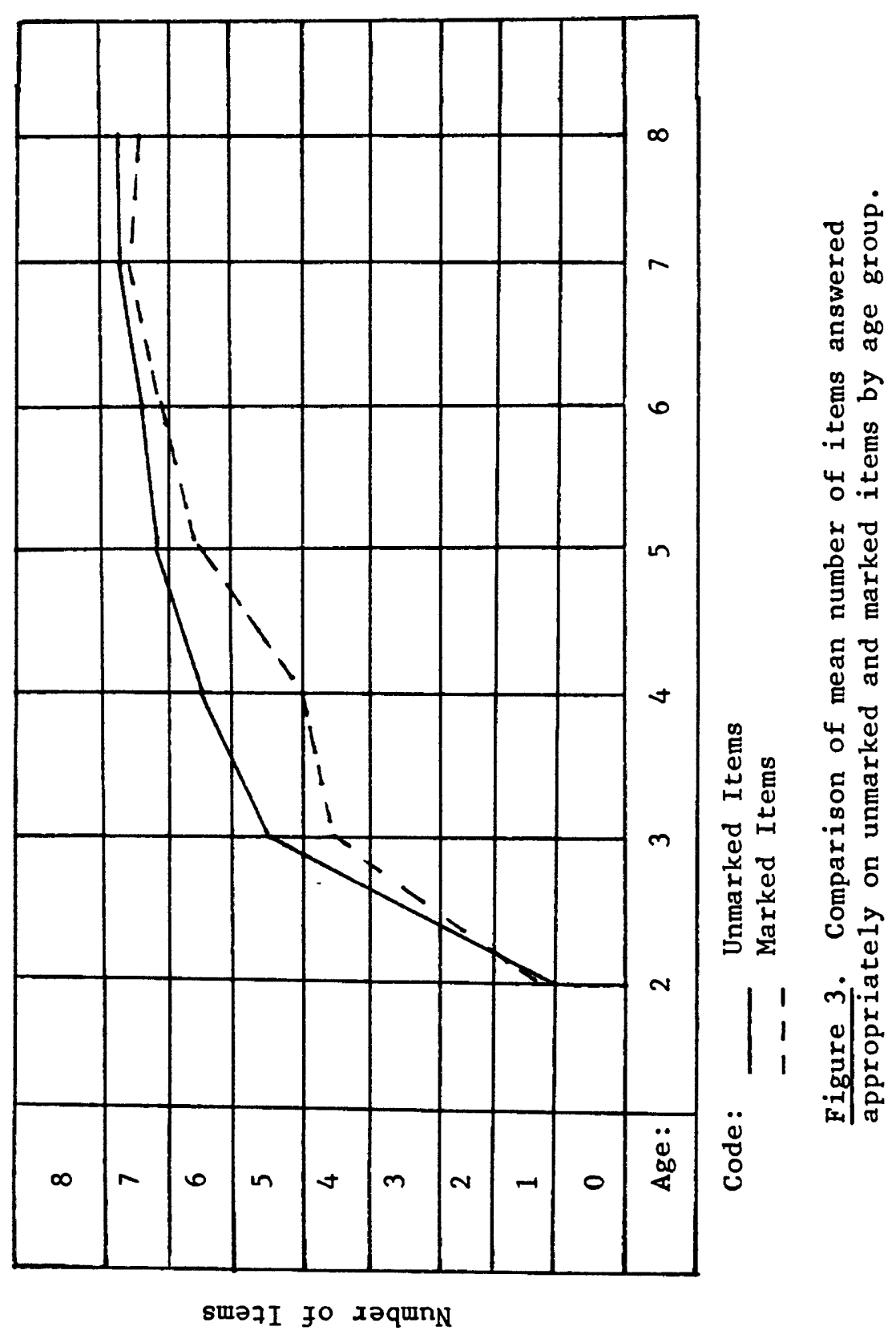




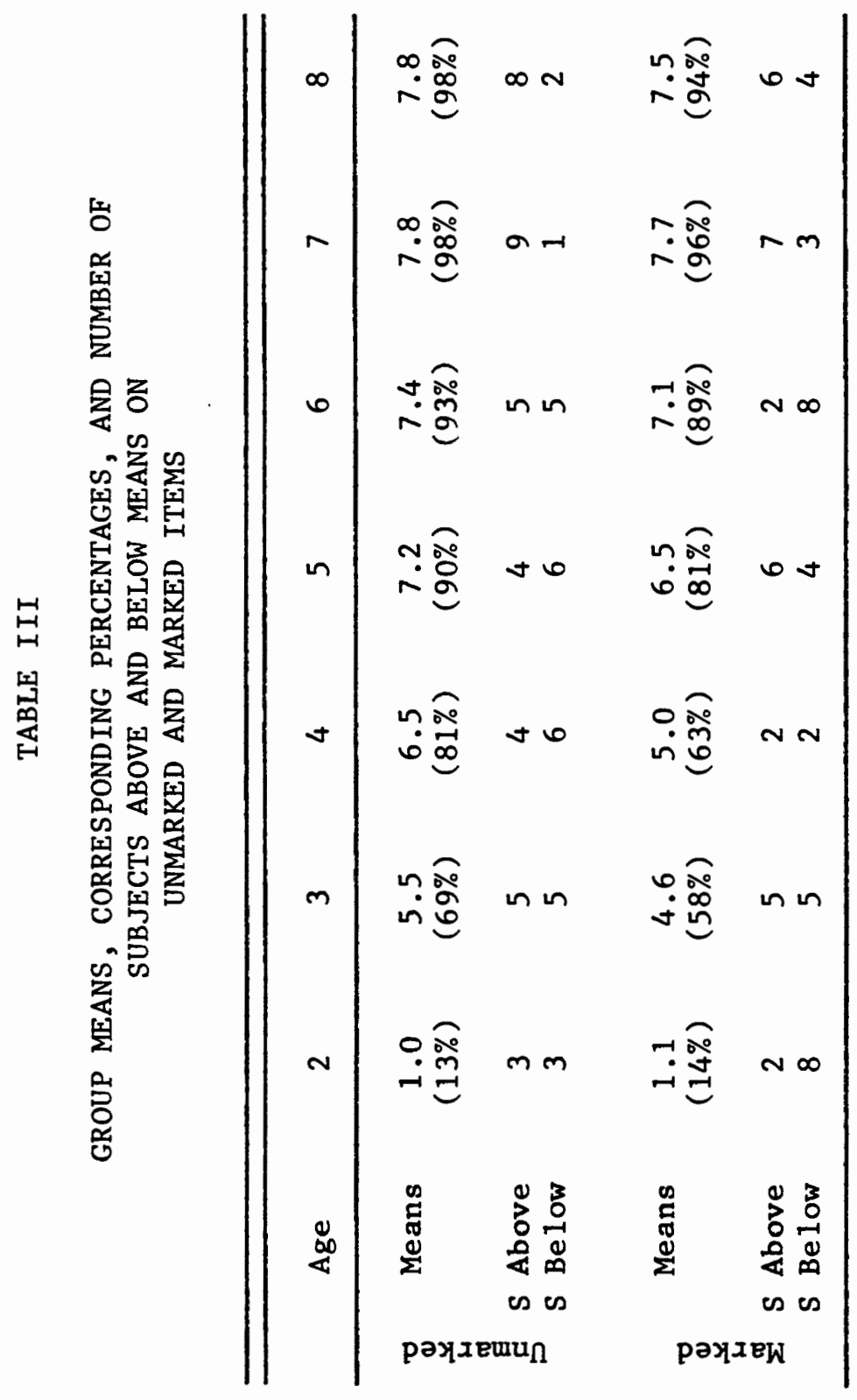


More children answered at least 80 percent of the unmarked items appropriately at five of the seven age groups. The difference at four years was most evident for unmarked and marked items. By five years of age, 10 (100 percent) and 8 (80 percent) of the children answered at least 75 percent of the unmarked and marked items appropriately, respectively (see Figure 4 and Table IV).

TABLE IV

PERCENTAGE OF SUBJECTS IN EACH AGE GROUP WHO

ANSWERED AT LEAST 75 PERCENT OF UNMARKED

AND MARKED ITEMS APPROPRIATELY

\begin{tabular}{cccccccc}
\hline Age & 2 & 3 & 4 & 5 & 6 & 7 & 8 \\
\hline Unmarked & $0 \%$ & $50 \%$ & $100 \%$ & $100 \%$ & $100 \%$ & $100 \%$ & $100 \%$ \\
Marked & $0 \%$ & $0 \%$ & $20 \%$ & $80 \%$ & $100 \%$ & $100 \%$ & $100 \%$ \\
\hline
\end{tabular}

A Treatment-by-Subjects Design was performed at each age level to determine the statistical significance of the difference in responses between unmarked and marked items. Table V demonstrates that the differences in scores were not significant at the .05 level of confidence for two-, four-, five-, six-, seven- and eight-year-old participants (see Tables V, VII, VIII, IX, X and XI). Table VI does, however, demonstrate a significant difference between unmarked and marked adjectives at the .05 level of confidence for the three-year group. 


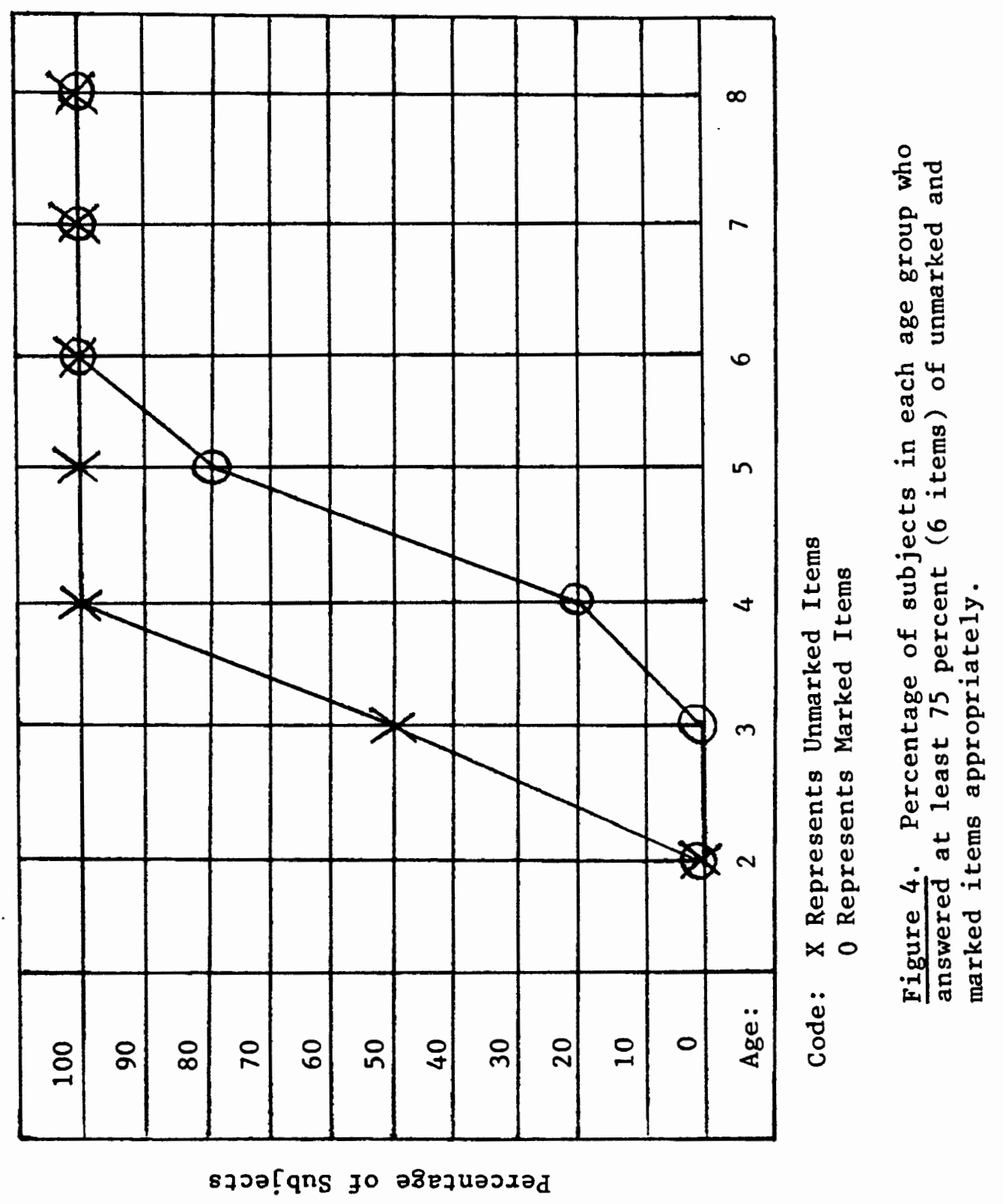


TABLE $\mathrm{V}$

ANALYSIS OF VARIANCE OF UNMARKED

AND MARKED ADJECTIVES FOR

TWO YEAR OLDS

\begin{tabular}{lccccc}
\hline Source & $\begin{array}{l}\text { Sum of } \\
\text { Squares }\end{array}$ & df & $\begin{array}{c}\text { Mean } \\
\text { Square }\end{array}$ & F & p \\
\hline Total & 1430 & 19 & & & \\
Subjects & 695 & 9 & & .099 & $>05$ \\
Treatments & 8 & 1 & 8 & & \\
Error & 727 & 9 & 80.78 & & \\
\hline
\end{tabular}

TABLE VI

ANALYSIS OF VARIANCE OF UNMARKED

AND MARKED ADJECTIVES FOR

THREE YEAR OLDS

\begin{tabular}{|c|c|c|c|c|c|}
\hline Source & $\begin{array}{l}\text { Sum of } \\
\text { Squares }\end{array}$ & $d f$ & $\begin{array}{c}\text { Mean } \\
\text { Square }\end{array}$ & F & $\mathrm{p}$ \\
\hline Total & 4298 & 19 & & & \\
\hline Subjects & 2473 & 9 & & & \\
\hline Treatments & 1260 & 1 & 1260 & 20.07 & $*<.05$ \\
\hline Error & 565 & 9 & 62.78 & & \\
\hline
\end{tabular}

*Significant 
TABLE VII

ANALYSIS OF VARIANCE OF UNMARKED

AND MARKED ADJECTIVES FOR

FOUR YEAR OLDS

\begin{tabular}{lllcll}
\hline Source & $\begin{array}{l}\text { Sum of } \\
\text { Squares }\end{array}$ & df & $\begin{array}{c}\text { Mean } \\
\text { Square }\end{array}$ & F & P \\
\hline Total & 4298 & 19 & & & \\
Subjects & 2473 & 9 & & 3.33 & $>.05$ \\
Treatments & 1857 & 1 & 1857 & & \\
Error & 5016 & 9 & 557 & &
\end{tabular}

TABLE VIII

ANALYSIS OF VARIANCE OF UNMARKED

AND MARKED ADJECTIVES FOR

FIVE YEAR OLDS

\begin{tabular}{lccccc}
\hline Source & $\begin{array}{c}\text { Sum of } \\
\text { Squares }\end{array}$ & df & $\begin{array}{c}\text { Mean } \\
\text { Square }\end{array}$ & F & p \\
\hline Total & 2498 & 19 & & & \\
Subjects & 1172 & 9 & & & \\
Treatments & 298 & 1 & 298 & 2.61 & 7.05 \\
Error & 1028 & 9 & 114.2 & & \\
\hline
\end{tabular}


TABLE IX

\section{ANALYSIS OF VARIANCE OF UNMARKED}

AND MARKED ADJECTIVES FOR

\section{SIX YEAR OLDS}

\begin{tabular}{lccccc}
\hline Source & $\begin{array}{l}\text { Sum of } \\
\text { Squares }\end{array}$ & df & $\begin{array}{c}\text { Mean } \\
\text { Square }\end{array}$ & F & P \\
Total & 1118 & 19 & & & \\
Subjects & 574 & 9 & & 1.3 & 7.05 \\
Treatments & 69 & 1 & 69 & & \\
Error & 475 & 9 & 53 & & \\
\hline
\end{tabular}

TABLE $X$

ANALYSIS OF VARIANCE OF UNMARKED

AND MARKED ADJECTIVES FOR

SEVEN YEAR OLDS

\begin{tabular}{lccccc}
\hline Source & $\begin{array}{l}\text { Sum of } \\
\text { Squares }\end{array}$ & df & $\begin{array}{c}\text { Mean } \\
\text { Square }\end{array}$ & $F$ & $p$ \\
Total & 898 & 19 & & & \\
Subjects & 664 & 9 & & .3185 & $>.05$ \\
Treatments & 8 & 1 & 8 & & \\
Error & 226 & 9 & 25.11 & & \\
\hline
\end{tabular}


TABLE XI

ANALYSIS OF VARIANCE OF UNMARKED

AND MARKED ADJECTIVES FOR

EIGHT YEAR OLDS

\begin{tabular}{|c|c|c|c|c|c|}
\hline Source & $\begin{array}{l}\text { Sum of } \\
\text { Squares }\end{array}$ & $d f$ & $\begin{array}{c}\text { Mean } \\
\text { Square }\end{array}$ & $\mathrm{F}$ & $\mathrm{p}$ \\
\hline Total & 1022 & 19 & & & \\
\hline Subjects & 632 & 9 & & & \\
\hline Treatments & 70 & 1 & 70 & 1.64 & $>.05$ \\
\hline Error & 383 & 9 & 42.55 & & \\
\hline
\end{tabular}

\section{Discussion}

By investigating the comprehension of various spatial adjectives by young children, this study sought the answer to two questions. The major question asked was, "At what age levels do children comprehend the polar forms of various spatial adjectives?" The results, as indicated in Table II, show a positive relationship between the age of the children and their ability to receptively identify spatial adjectives. Table II demonstrates that each age group through the seven year level correctly identified a progressively higher percentage of the spatial adjectives. Children at the eight year level identified 96 percent of all spatial adjectives, showing a slight decline in the percentage of spatial adjectives correctly identified when compared to the seven year level at which children correctly identified 97 percent of all spatial adjectives. It is assumed that if more subjects were included in the study, the results would have followed the trend in which the number of 
adjectives increased with age, or the two groups would be shown to be equal in the comprehension of spatial adjectives. It should be noted that the difference between the seven and eight year level seems unremarkable.

Results of this study support Wood's (1976) and Entwisle's (1966) contention that antonym forms continue to be acquired in the second grade. Data further support Entwisle's (1966) suggestion that there is a substantial increase in the use of adjectives between kindergarten and the third grade, although receptively, the most obvious growth, as shown by this investigation, occurred at the preschool level between two and three years of age.

Data do not lend support to E. Clark's (1972) study which revealed the following hierarchy in the expression of spatial adjectives: long-short, followed by tall-short, high-low, thick-thin, wide-narrow and deep-shallow. The present study revealed acquisition of "little," "big," (vs. 1ittle), "low," "tall" and "deep" at the three year level, followed by "high," "short," (vs. tal1), "long," "big," (vs. sma11) and "sma11" at the four year level. At five years of age, "wide," "narrow" and "short" (vs. 1ong) were considered to be present, "thin" at six years and "shallow" and "thick" at seven years of age. It is interesting to note that the adjectives which seem to be acquired first contain the earlier developing phonemes (e.g., big, deep), whereas those acquired later contain later developing phonemes (e.g., thick, thin, shallow).

The second question asked in this study was, "Is there a difference in the age levels of comprehension of unmarked versus marked adjective forms?" Results as indicated in Tables V, VI, VII, VIII, IX, 
$X$ and $X I$ demonstrate an insignificant difference in unmarked versus marked adjective forms except at the three year level. These results are not compatible with Clark's (1973) Complexity Hypothesis which explains that the positive (unmarked) member is acquired before the negative (marked) member of the pair. The present study generally supports the E. Clark (1972) and Illerbrun (1975) investigations which demonstrated that children comprehend (I11erbrun, 1975) and express (E. Clark, 1972) the unmarked member at the same time as the marked member of adjective pairs. Table VI, however, shows a significant difference in unmarked versus marked adjective forms at the three year level.

The difference in comprehension at the three year level may have occurred as the result of a period of transition in learning spatial adjectives. It is also possible that the design of this study may have influenced the results because each child was tested on only one occasion; a longitudinal investigation may be more sensitive in demonstrating whether unmarked adjectives are acquired before marked items.

In analyzing test results (Table II), one notices significant differences in responses to the two "short" items. Appendix B illustrates the more abstract (page 41) and the more concrete representation (page 42) of the adjective. It is this investigator's impression that some of the children were unsure of the procedures of the test which began with the most abstract concept included, i.e., "short." It is suspected that if the order of presentation had been changed with the abstract representation of "short" administered later in the testing sequence, results may have been more consistent between the abstract and concrete representations of "short." One may wish to include at 
least two samples before proceeding with actual test administration to confirm the child's familiarity with the test items and the procedures, thereby avoiding any doubts concerning actual performance rather than confusion about the test protocol. A similar, but less notable difference occurred with the two "big" items as illustrated in Appendix B (pages 46 and 51). The difference occurred at two and three years of age, although both items were considered to be concrete.

Essentially, the results of this study indicate that children probably comprehend those spatial adjectives with which they have had the most experience. For example, children probably have more occasion to encounter "big" and "little" and "high" and "Iow" when compared to "deep" and "shallow" as reflected in Table II. Exceptions would be expected to occur based on individual experiences with each concept. 
CHAPTER V

SUMMARY AND IMPLICATIONS

\section{$\underline{\text { Summary }}$}

There has been considerable interest in the child's acquisition of spatial adjectives. However, few studies have investigated the significance of age on the child's comprehension of spatial adjectives in their polar (e.g., wide-narrow), comparative (e.g., wider-narrower) and superlative (e.g., widest-narrowest) forms.

The purpose of this study was to determine the significance of chronological age on the comprehension of spatial adjectives in children. Specifically, the investigation set out to determine the age levels at which children comprehend the polar forms of various spatial adjectives and to determine the difference in age levels of comprehension of unmarked versus marked adjective forms. Seventy children between the ages of two years, \pm 2 months and eight years, \pm 2 months, selected on the basis of chronological age, normal receptive vocabulary recognition and normal hearing, participated as subjects.

The results showed a positive relationship between age of the children and their ability to receptively identify spatial adjectives. Each age group through the seven year olds identified a progressively higher percentage of spatial adjectives. The results also suggest overall insignificant differences in the comprehension of unmarked versus marked adjective forms with the exception of three year old 
subjects.

\section{Implications}

$\underline{\text { Research }}$

This investigation has demonstrated a trend indicating an increase in the comprehension of spatial adjectives with age. While results of this study appear not to agree with those of E. Clark's (1972) investigation, one must recognize that the present study dealt with receptive acquisition rather than expressive; comparisons may be invalid. Considering, however, that receptive language skills presumedly precede expressive language skills and the fact that there are discrepancies in the results of the two studies relative to order of acquisition, it is suggested that further investigations include more than ten children at each age level to provide more valid data.

Subjects in this investigation were randomly selected from a "normal" population. Several children were excluded from the study because vocabulary scores achieved on the Peabody Picture Vocabulary Test, Form A (1971) were more than six months above chronological age. Because of the frequency of exclusion of subjects, it is this investigator's impression that the Peabody Picture Vocabulary Test, Form A (Dunn, 1971) norms may not be representative for 1980. A telephone conversation with Dunn indicated that the data have been revised recently. It is suggested the new Peabody Picture Vocabulary Test-R (Dunn, 1979) norms be used when controlling for receptive vocabulary in subsequent studies.

It may be of interest to conduct research on the age of acquisi- 
tion of expressive spatial adjectives in their polar, comparative and superlative forms as well as investigations involving other adjective types, such as size and shape. A longitudinal study in which the subjects are tested every two months would clarify the data concerning the acquisition of unmarked versus marked adjectives. Determination of the effect of socioeconomic status on the comprehension and/or expression of adjectives is also further suggested.

\section{Clinical}

As stated in the review of the literature, current standardized tests examined by this investigator provide data for no more than three items pertaining to any form of adjectives; age levels of comprehension were not included. The data collected in this study have provided age levels and the order of comprehension of selected spatial adjectives which are important guidelines for consideration of language development. The information will provide valuable facts to aid in the identification of language delayed and disordered individuals and will provide a starting point in the management of deviant adjective comprehension. 


\section{SELECTED BIBLIOGRAPHY}

ANGLIN, T., The Growth of Word Meaning. Massachusetts: MIT Press $(1970)$.

BANKśoN, N., Bankson Language Screening Test. Baltimore: University Park Press (1977).

BERKO, J., The child's learning of English morphology. Word, 14, 150-177 (1958).

BIERWISCH, M., Some semantic universals of German adjectivals. Foundations of Language, 3, 1-36 (1967).

BOEHM, A., Test of Basic Concepts. New York: Psychological Corporation (1969).

BREWER, W., and LICHTENSTEIN, E., Memory for marked semantic features versus memory for meaning. J. Verb. Learn. Behav., 13, 172-180 (1974).

BRUNING, J., and KINTZ, B., Computational Handbook of Statistics. Illinois: Scott, Foresman and Company (1977).

CARPENTER, P., On the comprehension, storage and retrieval of comparative sentences. J. Verb. Learn. Behav., 13, 401-411 (1974).

CARROW, E., Test for Auditory Comprehension of Language. Texas: Urban Research Group (1973).

CHOMSKY, N., Aspects of the Theory of Syntax. Cambridge, Massachusetts: MIT Press (1965).

CHOMSKY, N., Language and Mind. New York: Harcourt (1968).

CLARK, E., On the child's acquisition of antonyms in two semantic fields. J. Verb. Learn. Behav., 11, 750-758 (1972).

CLARK, $\mathrm{H} .$, Influence of language on solving three-term series problems. J. Exp. Child. Psychol., 82, 205-215 (1969).

CLARK, H., The primitive nature of children's relational concepts. In J. Hayes (Ed.), Cognition and the Development of Language. New York: John Wiley and Sons, Inc. (1970).

CLARK, H., More about "adjectives, comparatives, and syllogisms": A reply to Huttenlocher and Higgins. Psychol. Rev., 78, 505-514 
(1971).

CLARK, H., Space, time, semantics and the child. In T. Moore (Ed.), Cognitive Development and the Acquisition of Language. New York: Academic Press (1973).

CLARK, H., and CARD, S., Role of semantics in remembering comparative sentences. J. Exp. Child Psychol., 82, 545-553 (1969).

CRIPPLED CHILDREN'S DIVISION, University of Oregon Medica1 Schoo1, Manual for Evaluation of Speech, Language and Hearing Development in Children. Portland, Oregon: University of Oregon Medical Schoo1 (1958).

DAIE, P., Language Development: Structure and Function. New York: Holt, Rinehart and Winston (1976).

DONALDSON, M., and WALES, R., On the acquisition of some relational terms. In J. Hayes (Ed.), Cognition and the Development of Language. New York: Wiley (1970).

DUNN, L., Peabody Picture Vocabulary Test. Minneapolis: American Guidance Service, Inc. (1971).

DUNN, L., Peabody Picture Vocabulary Test-R. Minneapolis: American Guidance Service, Inc. (1979).

EHRI, L., and RICHARDSON, D., Antonym adjective contexts and the facilitation of noun-pair learning in children. J. Verb. Learn. Behav., 11, 387-397 (1972).

EILERS, R., OLLER, D., and ELLINGTON, J., The acquisition of wordmeaning for dimensional adjectives: The long and short of it. J. Child Lang., 1, 195-204 (1975).

ENTWISLE, D., Form class and children's word associations. J. Verb. Learn. Behav., 5, 558-565 (1966).

GREENBERG, J., Language Universals. The Hague: Mouton (1966).

HUTTENLOCHER, J., and HIGGINS, E., Adjectives, comparatives and syllogisms. Psychol. Rev., 78, 487-504 (1971).

ILLERBRUN, D., The comprehension of spatial adjectives by children with normal and children with deviant language development. Human Comm. , 5, 27-36 (1975).

KLATZKY, R., CLARK, E., and MACKEN, J., Asymmetries in the acquisition of polar adjectives: Linguistic or conceptual? J. Exp. Child Psychol., 16, 32-46 (1973).

MCNE ILL, D., The Acquisition of Language. New York: Harper (1970). 
NELSON, K., Some attributes of adjectives used by young children. Cognition, 4, 13-30 (1976).

PALERMO, E., More about less: A study of language comprehension. J. Verb. Learn. Behav., 12, 211-221 (1973).

STRENG, A., Syntax, Speech and Hearing. New York: Grune and Stratton (1972).

VENDLER, Z., Adjectives and Nominalizations. The Hague: Mouton (1968).

WALES, R., and CAMPBELL, R., On the development of comparison and the comparison of development. In G. d'Arcais and W. Levelt (Eds.), Advances in Psycholinguistics. Amsterdam: North Holland (1970).

WEBSTER'S SEVENTH NEW COLLEGIATE DICTIONARY. Springfield: G. and C. Merriam Co. (1971).

WIIG, E., and SEMEL, E., Language Disabilities in Children and Adolescents. Ohio: Charles E. Merrill (1976).

wOOD, B., Children and Communication: Verbal and Nonverbal Language Development. Englewood Cliffs: Prentice-Ha11 (1976).

ZIMMERMAN, V., STEINER, V., and EVATT, R., Preschool Language Scale (1969). 
APPENDIX A

\section{PERMISSION FORM}

I agree/do not agree to let my child

participate as a subject entitled "Age and the Comprehension of Spatial Adjectives." This study is carried out by Barbara Cassidy under the supervision of Mary Gordon, thesis director, Speech and Hearing Sciences program, Portland State University.

The purpose of the study is to determine the ages at which normal children acquire various adjectives.

There are no risks or dangers inherent in the procedures of the study. My child will simply be asked to point to a series of pictures and to raise his/her hand upon hearing sounds. Subjects are free to withdraw from the study at any time.

\section{Signature of Parent/Guardian}

Date

Please return this form with your child tomorrow. If you have any questions, my home phone number is 287-6720.

If you experience problems which result from participation in this study, please contact Richard Streeter, office of Graduate studies and Research, 105 Neuberger Ha11, Portland State University, 229-3423. 


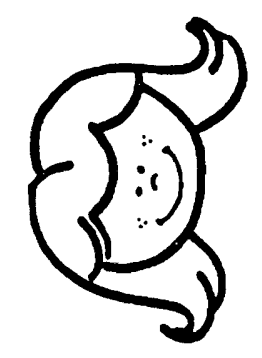

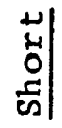
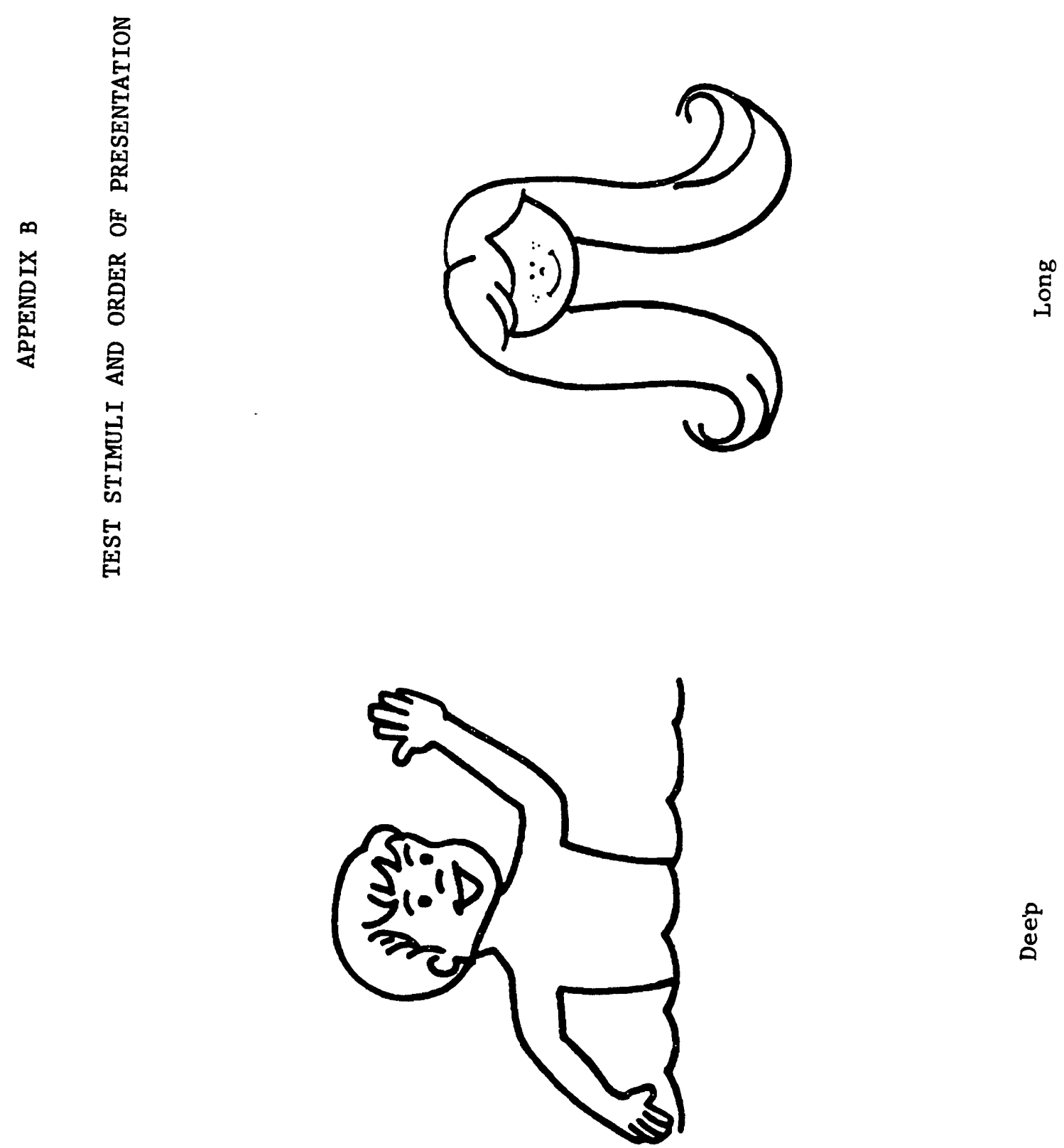

อับ 


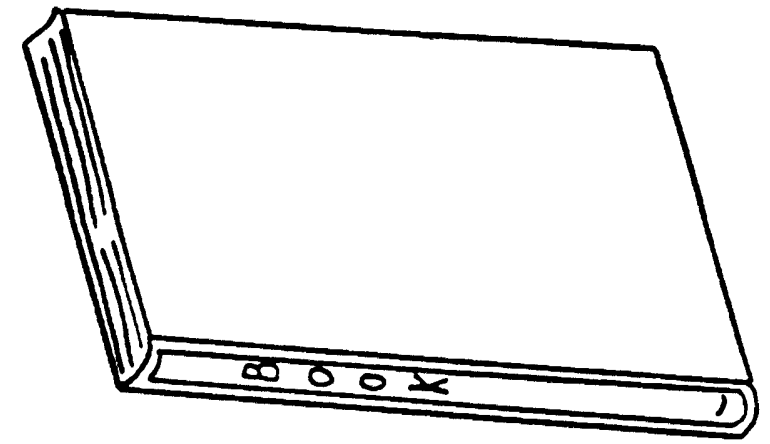

ED

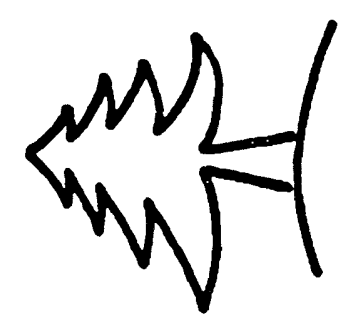

綮

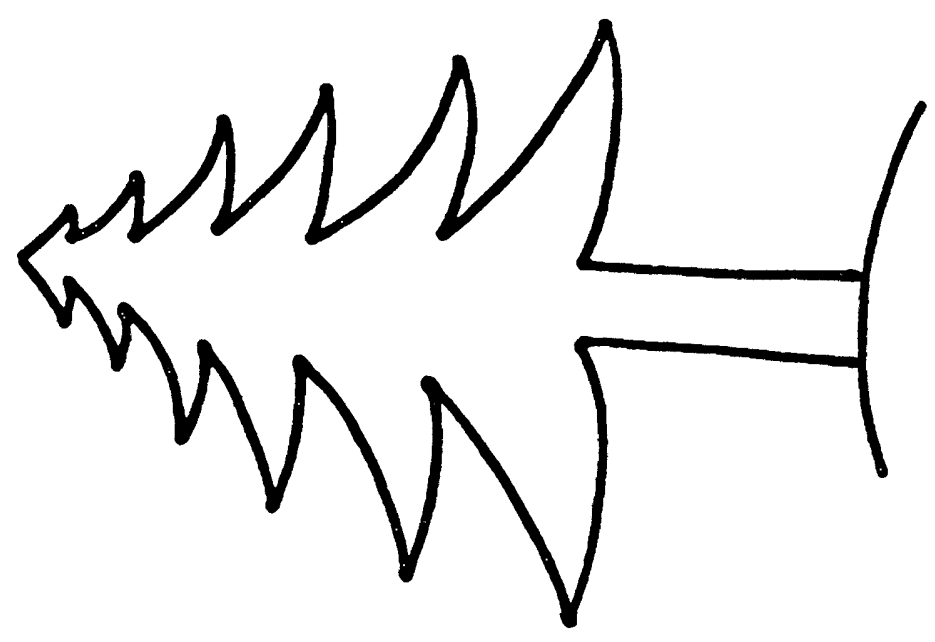

$\underset{\varpi}{\rightleftharpoons}$ 


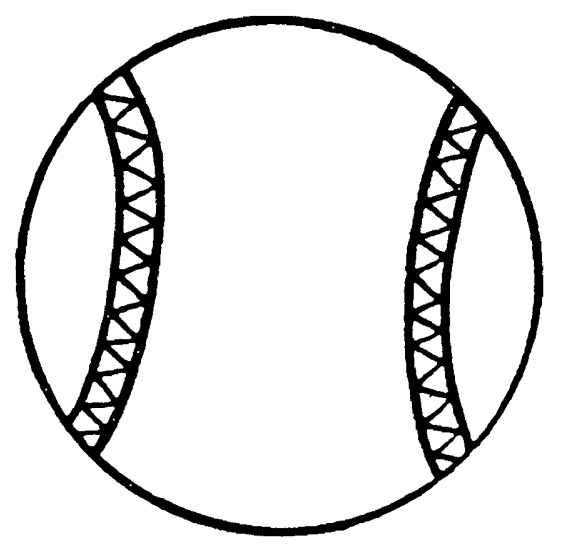

$\underbrace{\infty}_{\infty}$

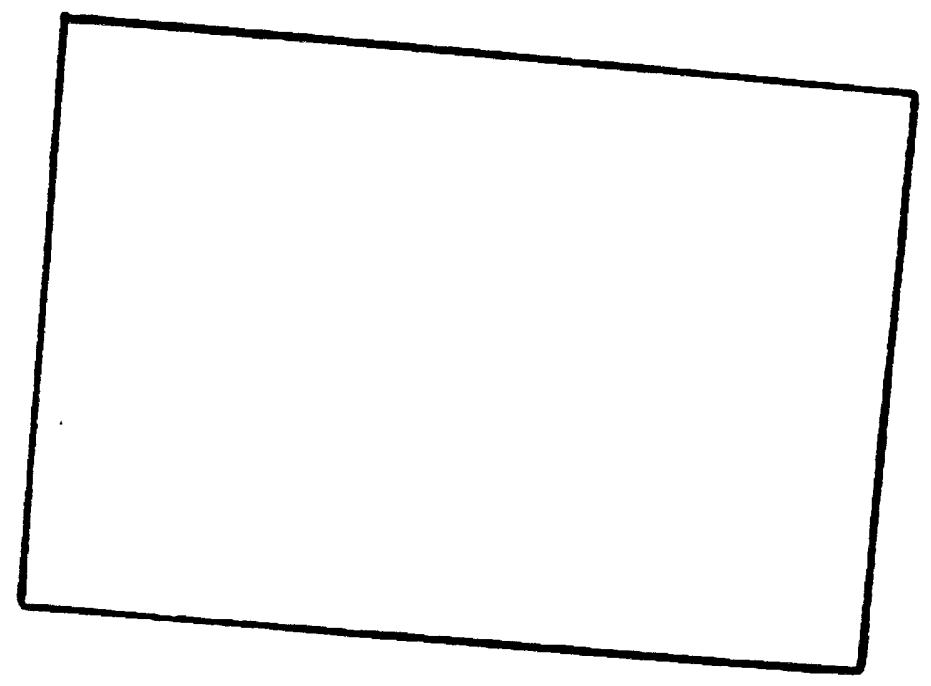

$\frac{8}{-7}$

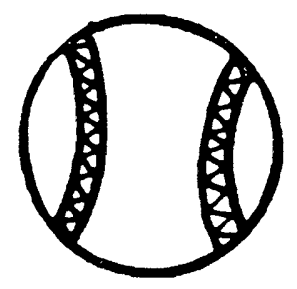

ํํำ 


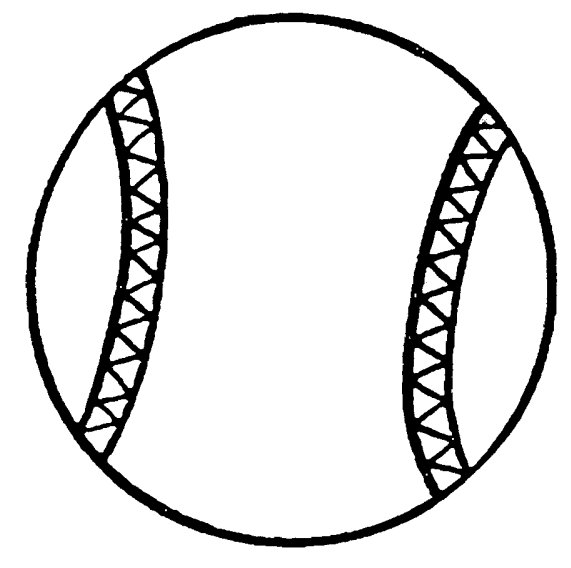

44

$\underset{\infty}{\infty}$

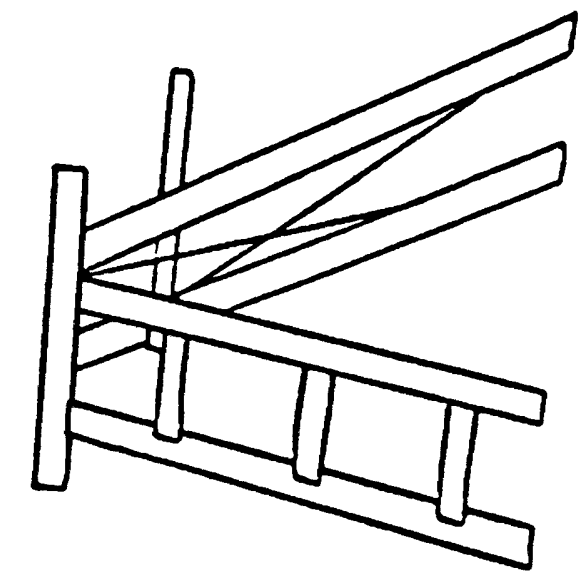

곡

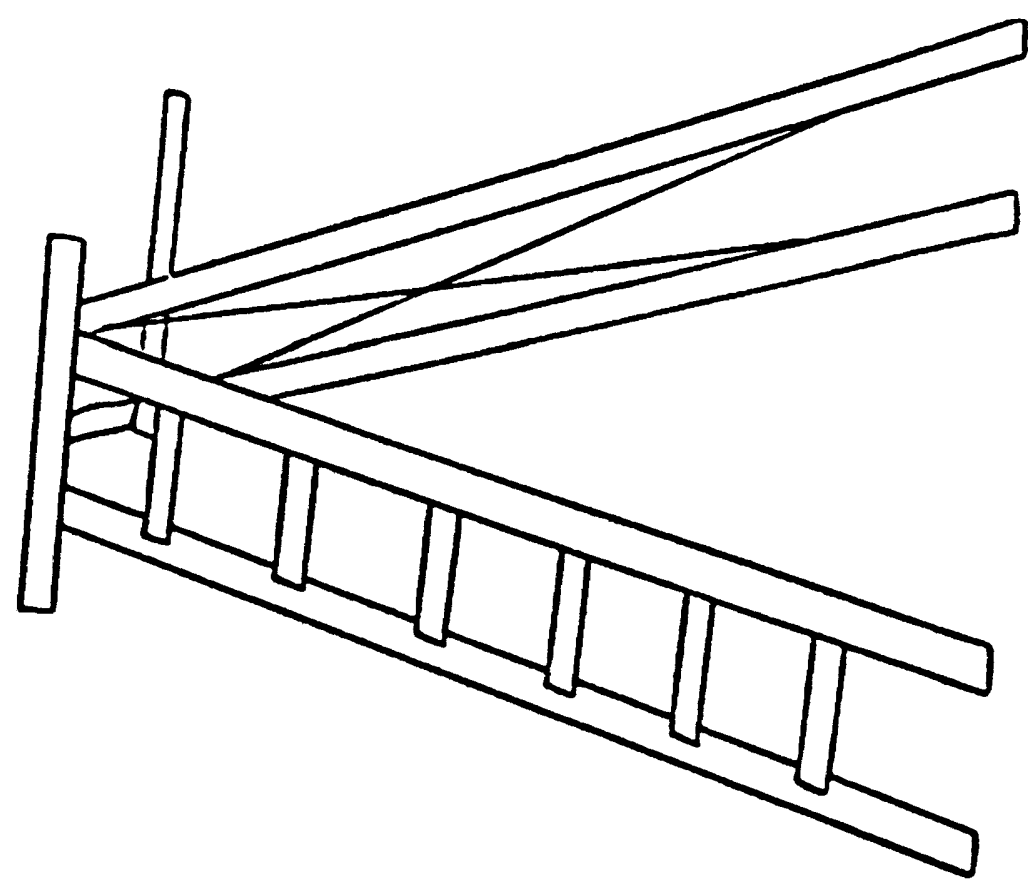

멍 


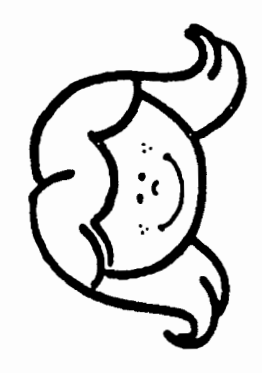

占

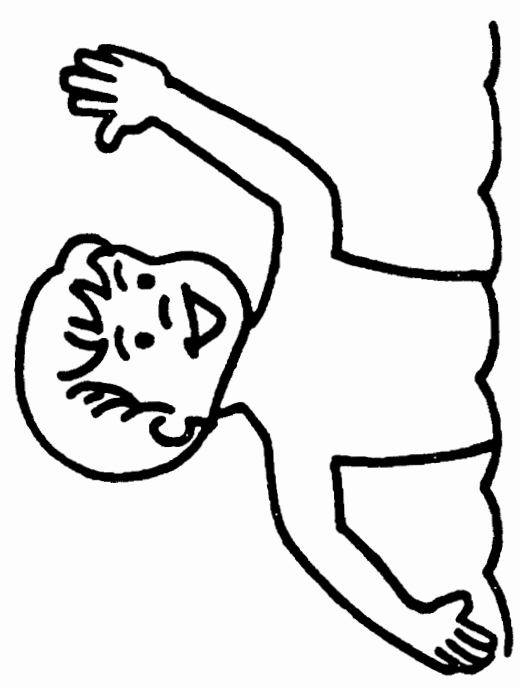

이

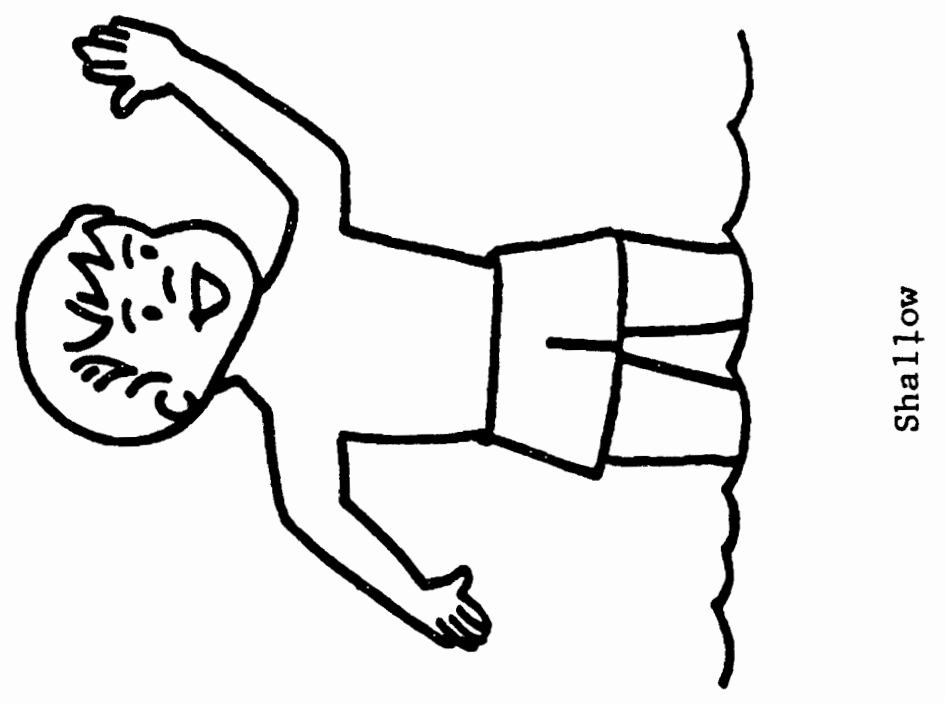




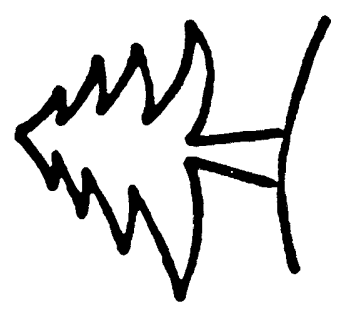

芩

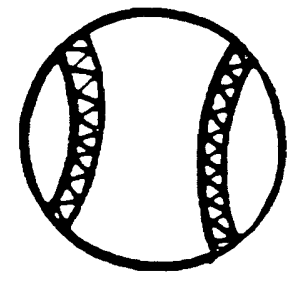

$\underset{+1}{ \pm-1}$

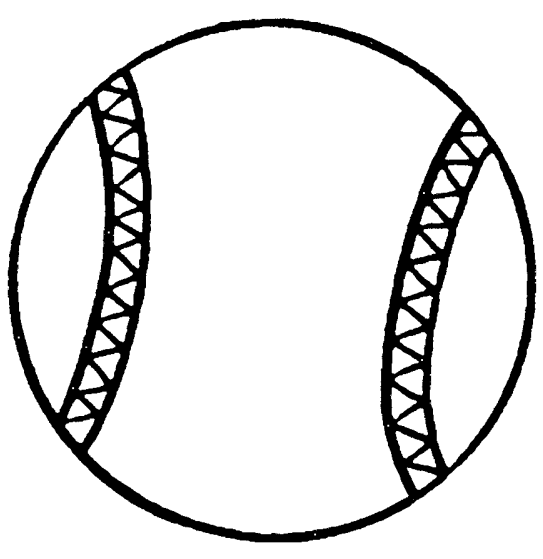

品 


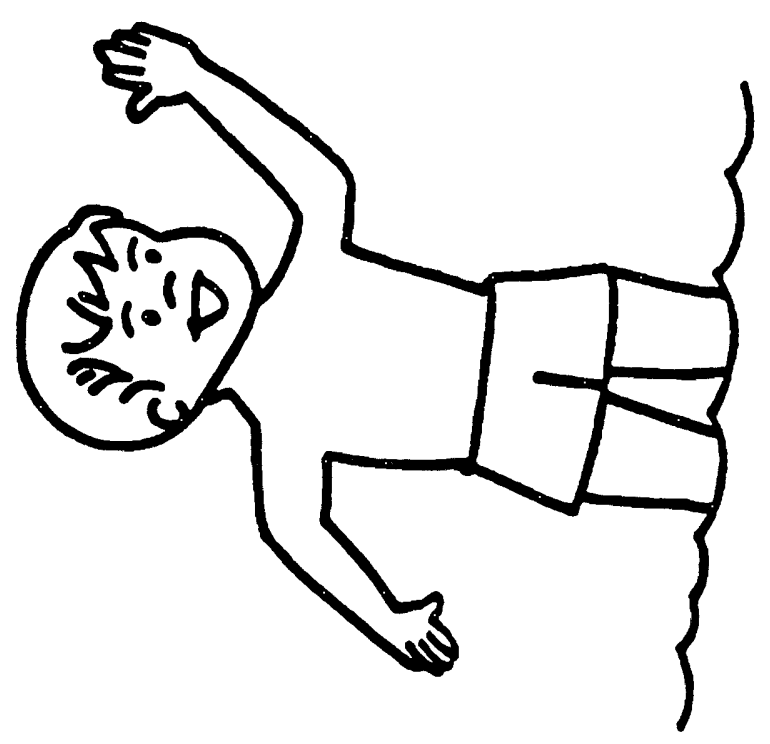

$\frac{3}{2}$

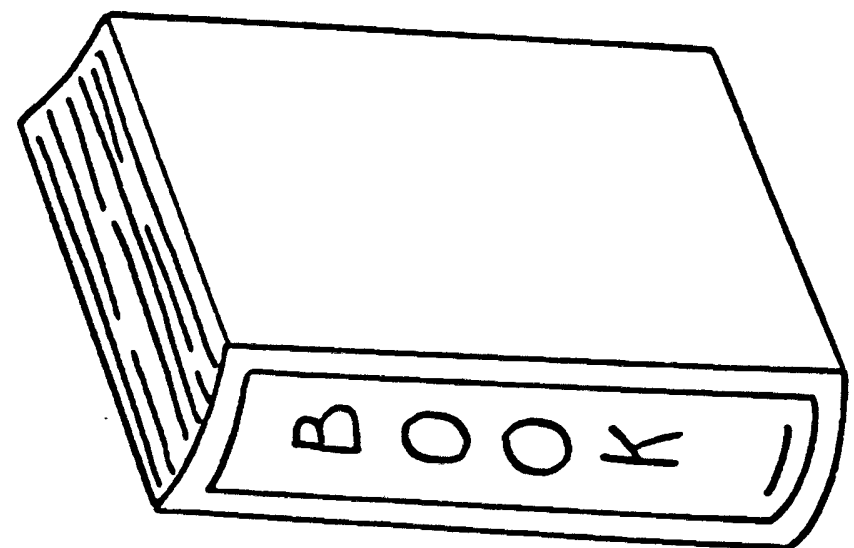

Ev

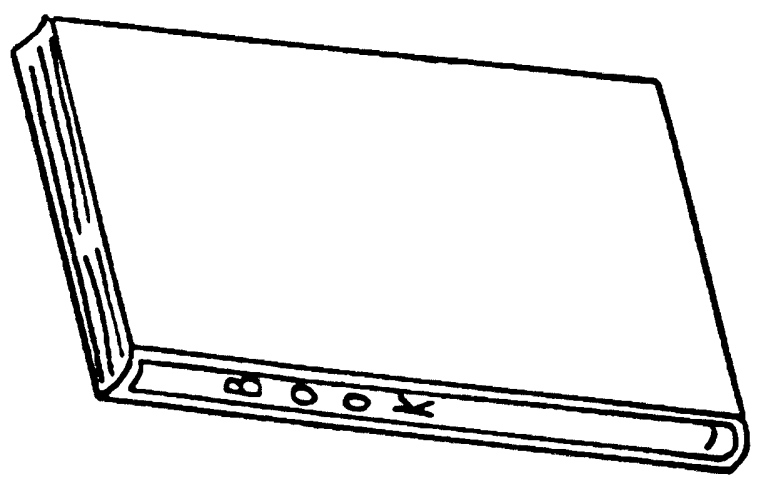




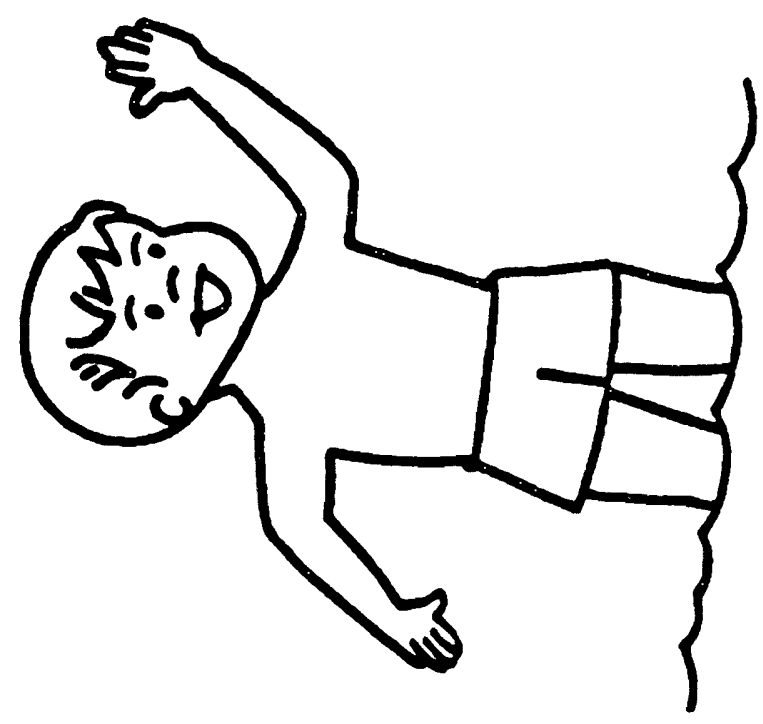

3
0
-7
0
$\frac{0}{\infty}$

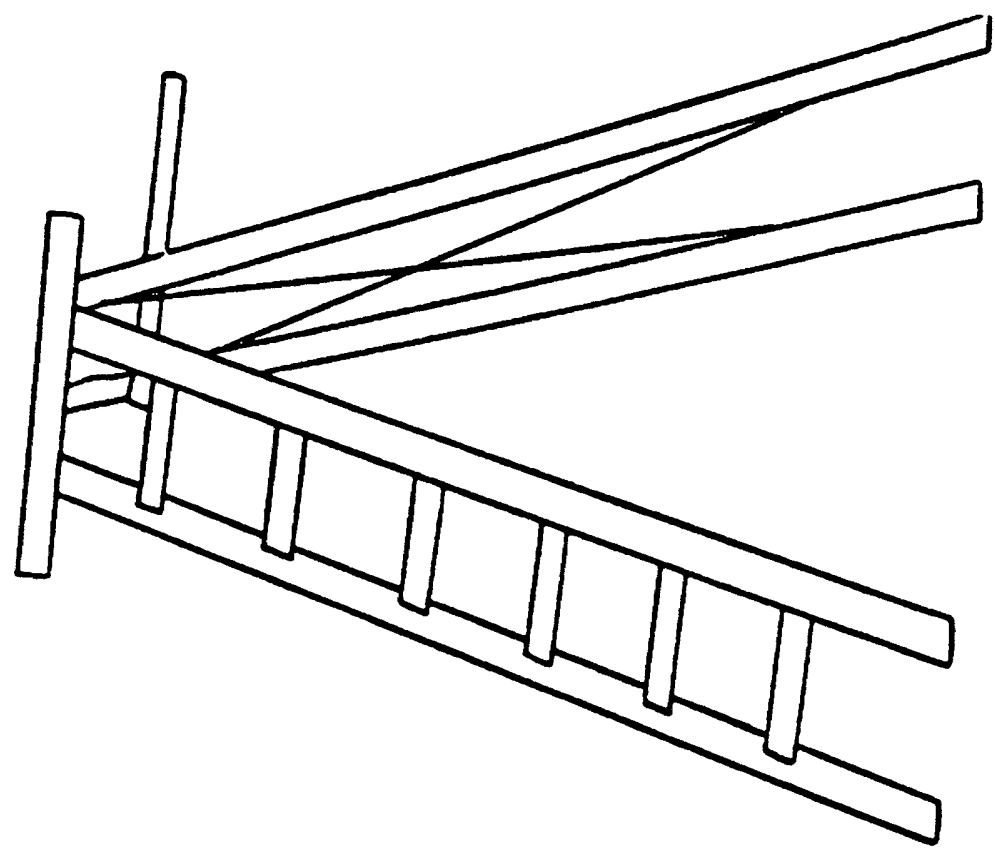

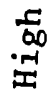

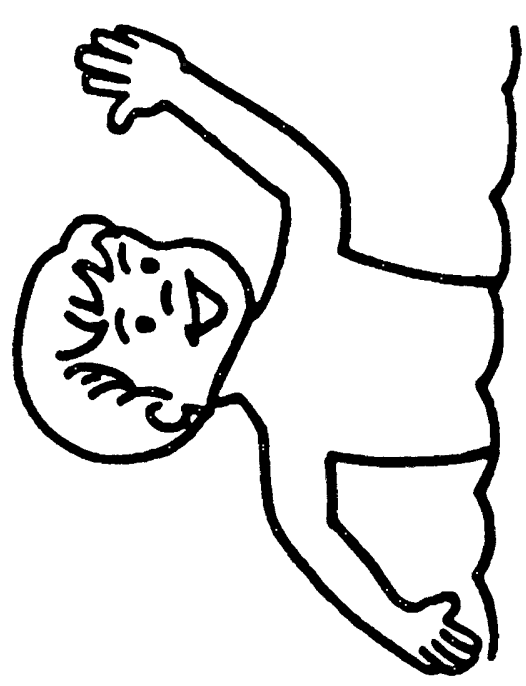

ปัญ 


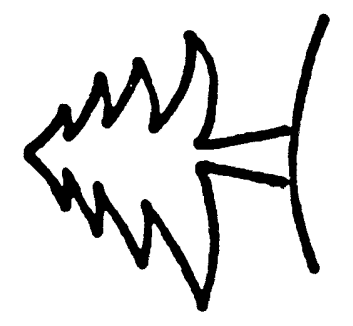

㟔

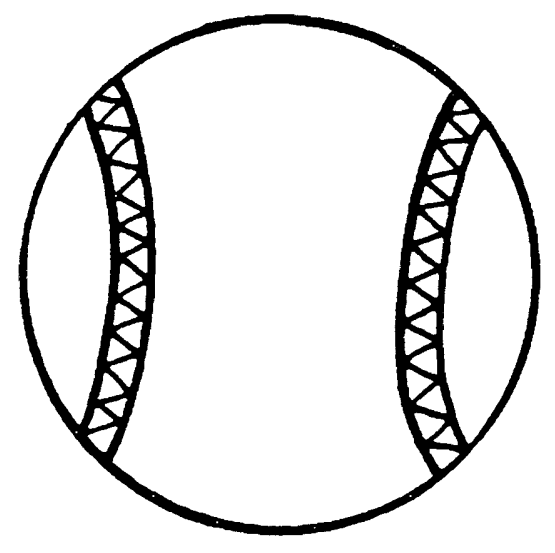

$\stackrel{\infty}{-\infty}$

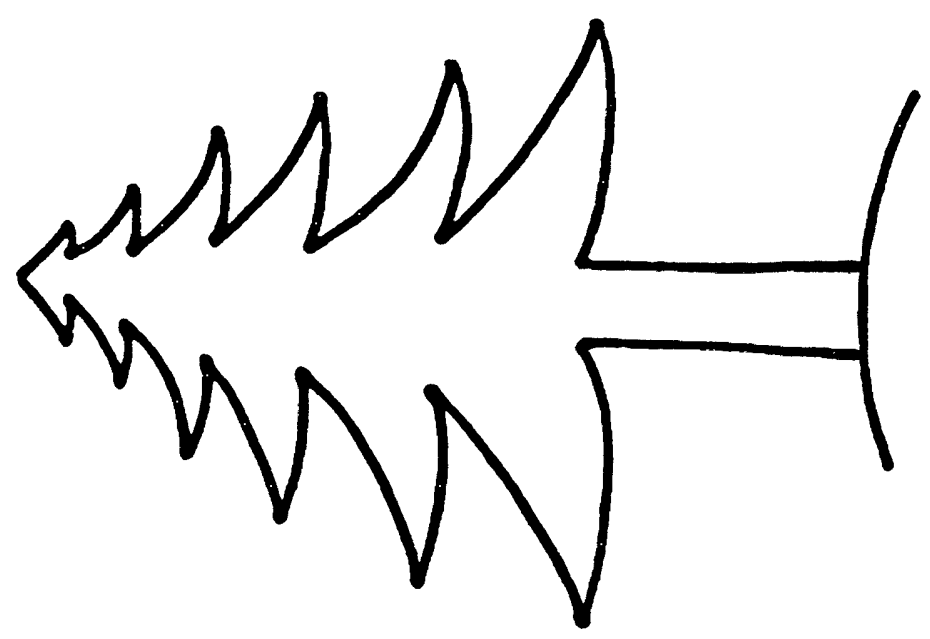

可 


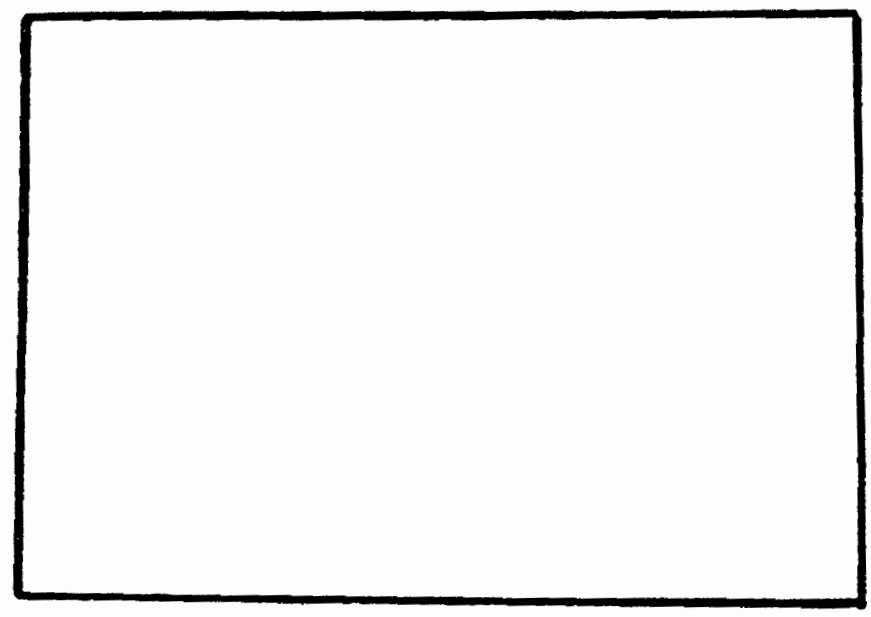

$\frac{0}{0}$

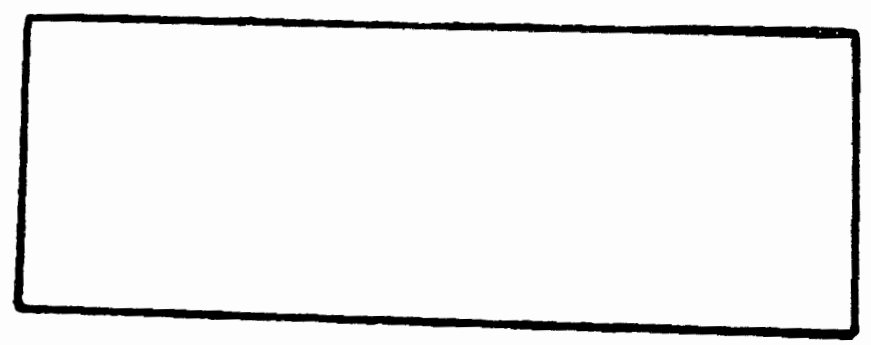

3
0
4
4
$\pi$
$z$

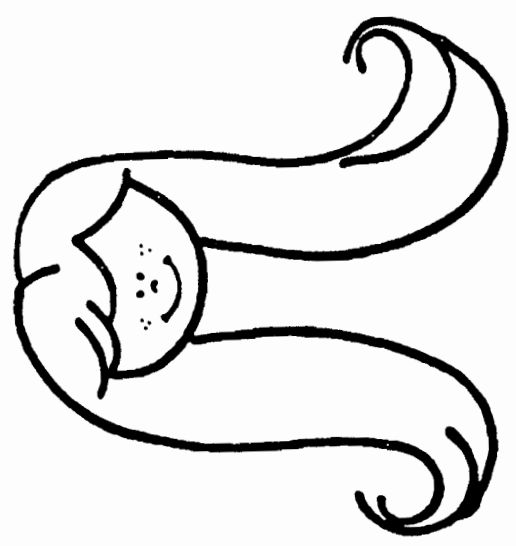

롬 


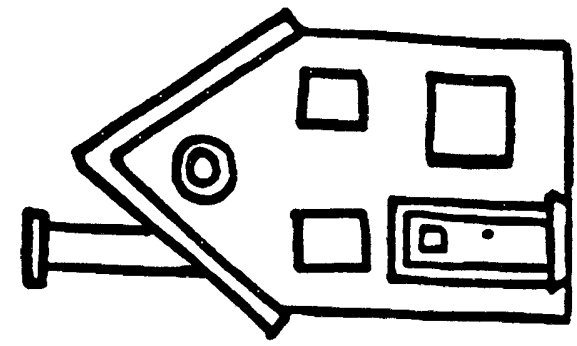

苞

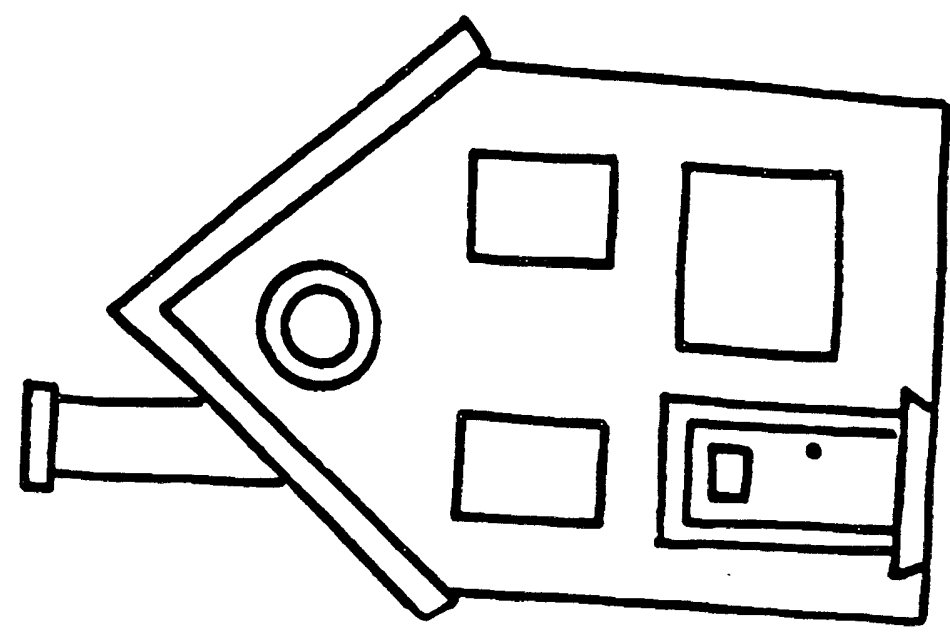

og
af

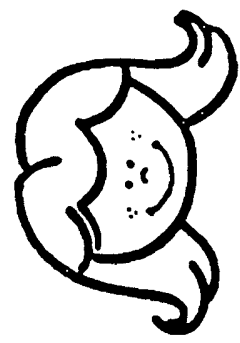

岁 


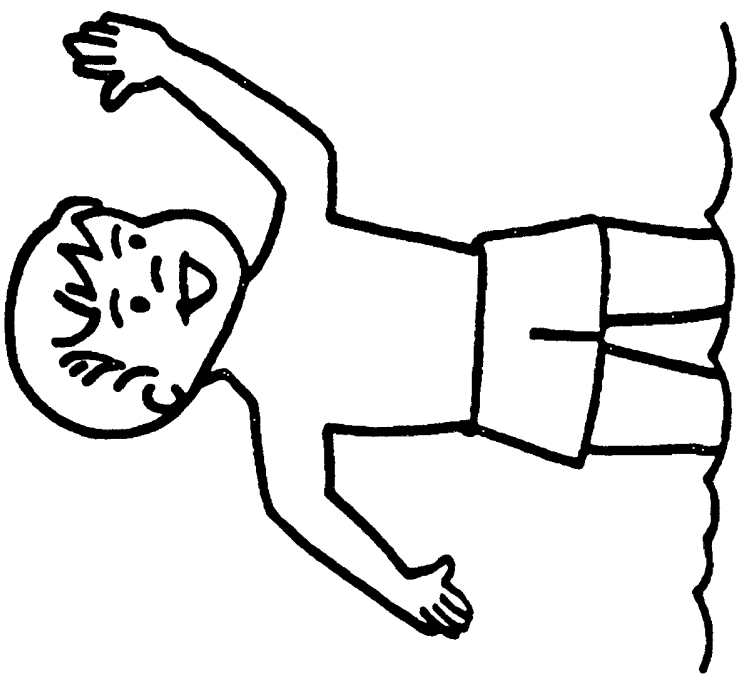

告

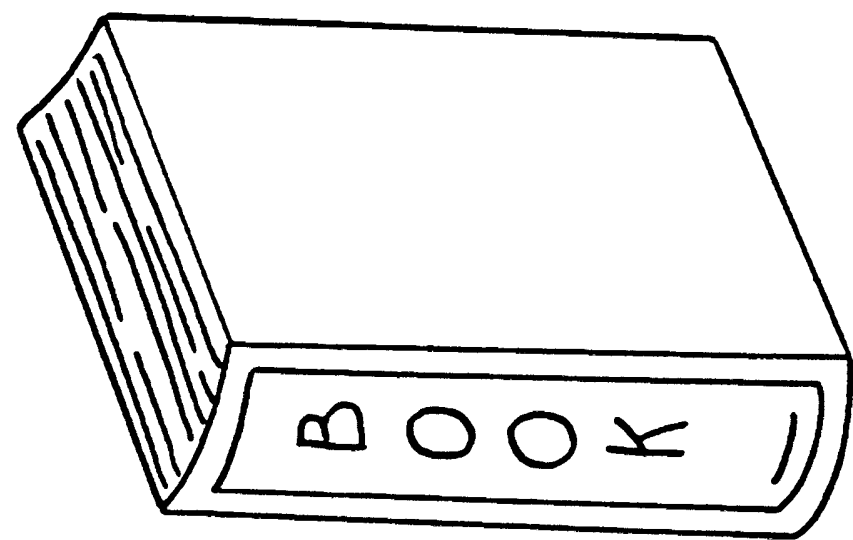

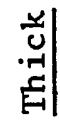

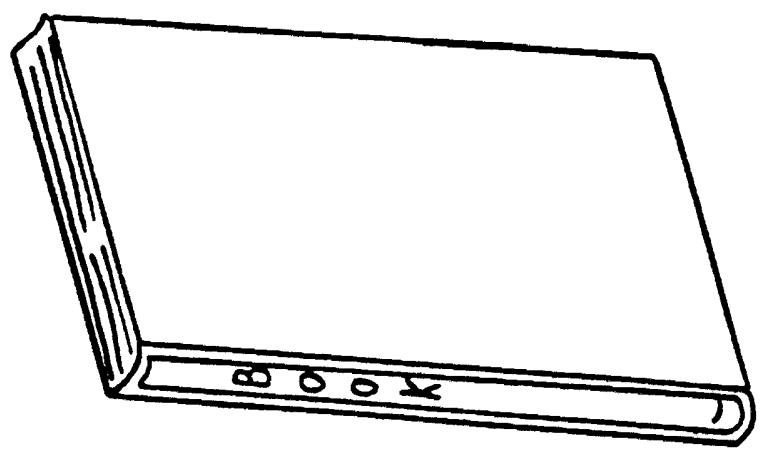

돌 


$$
\text { (1) }
$$




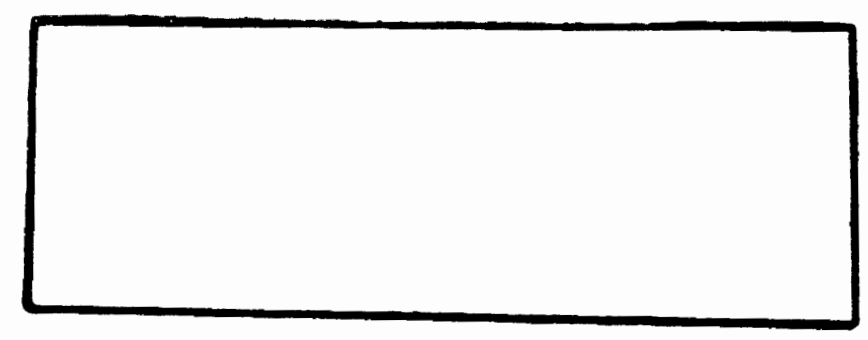

3
0
4
0
$z$
$z$

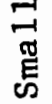

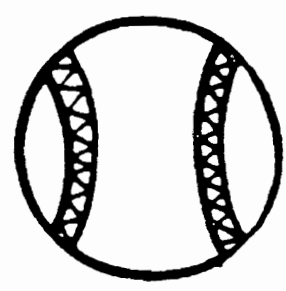

崩 



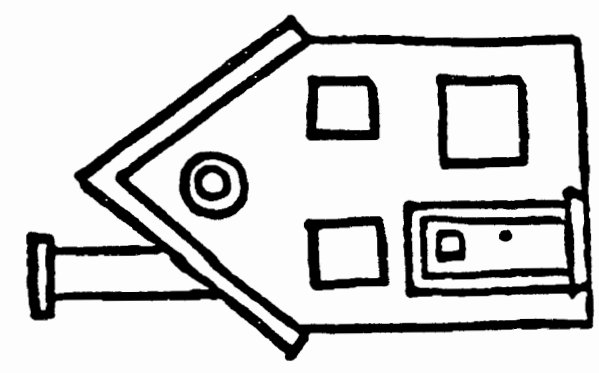

㤩

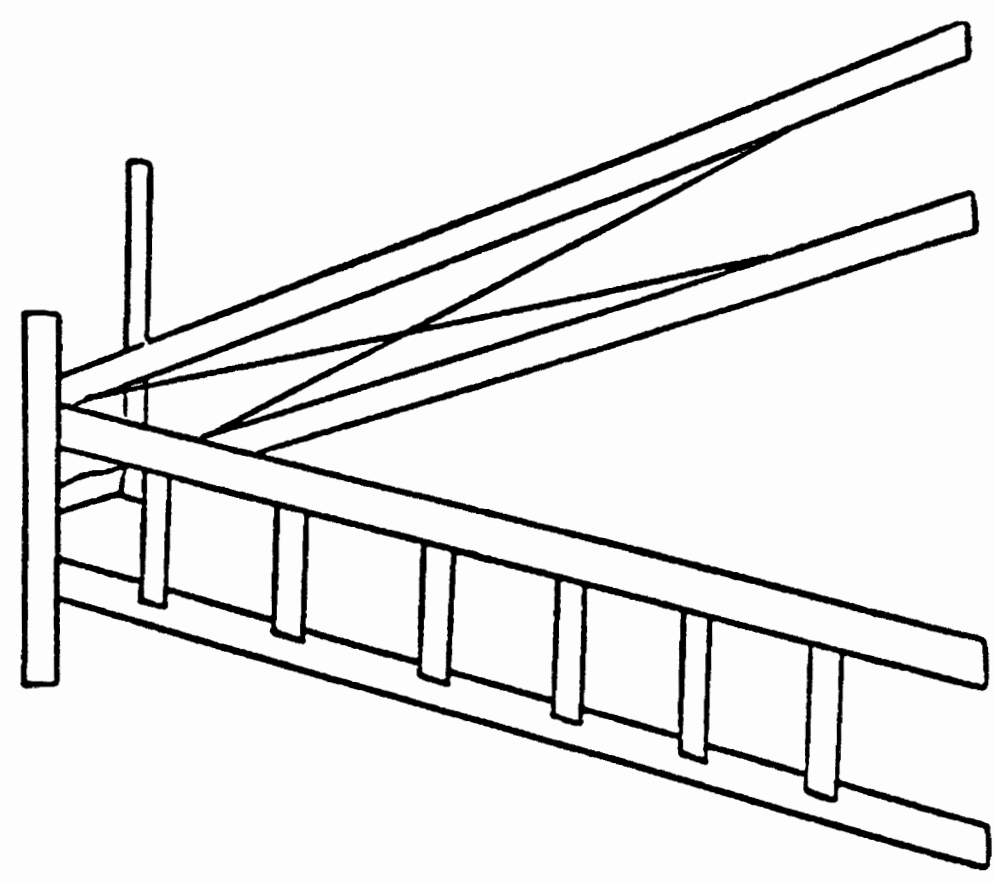

$\frac{2}{\infty 0}$
年

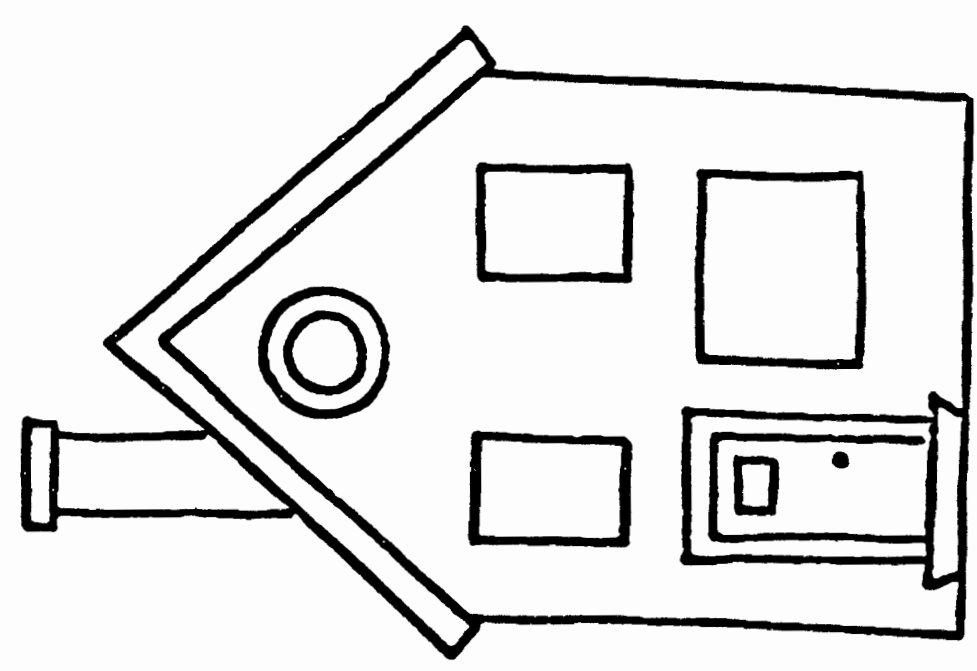

${ }_{n}^{\infty}$ 
TOTAL NUMBER CORRECT ADJECTIVES FOR EACH CHILD AT EACH AGE LEVEL

\begin{tabular}{lll}
\hline & & \\
Initials & Age on & Number \\
of Child & Test Date & $\begin{array}{l}\text { Correct } \\
\text { Cor }\end{array}$ \\
\hline & & \\
C.L. & 2.0 & 1 \\
E.B. & 2.0 & 4 \\
B.D. & 2.1 & 1 \\
M.W. & 1.11 & 2 \\
K.S. & 2.1 & 3 \\
M.G. & 1.11 & 2 \\
M.G. & 2.0 & 1 \\
C.K. & 1.11 & 3 \\
M.B. & 2.1 & 2 \\
B.K. & 1.11 & 2 \\
D.B. & 2.11 & 9 \\
K.R. & 3.0 & 10 \\
E.S. & 3.0 & 11 \\
J.L. & 2.11 & 10 \\
I.S. & 3.0 & 12 \\
D.K. & 3.0 & 6 \\
R.C. & 3.0 & 12 \\
J.C. & 2.10 & 8 \\
E.D. & 2.11 & 10 \\
R.S. & 3.1 & 9 \\
M.R. & 4.2 & 12 \\
M.A. & 4.1 & 12 \\
N.C. & 4.2 & 11 \\
C.A. & 3.10 & 9 \\
R.R. & 3.11 & 11 \\
J.B. & 3.11 & 13 \\
D.A. & 3.11 & 10 \\
A.P. & 4.2 & 13 \\
A.O. & 4.1 & 11 \\
A.S. & 3.11 & 13 \\
S.D. & 4.11 & 12 \\
I.Y. & 5.1 & 13 \\
D.N. & 5.0 & 14 \\
A.M. & 5.2 & 14 \\
A.M. & 4.11 & 13 \\
\hline & & \\
\hline
\end{tabular}

\begin{tabular}{|c|c|c|}
\hline $\begin{array}{l}\text { Initials } \\
\text { of Child }\end{array}$ & $\begin{array}{c}\text { Age on } \\
\text { Test Date }\end{array}$ & $\begin{array}{l}\text { Number } \\
\text { Correct }\end{array}$ \\
\hline S.H. & 5.2 & 12 \\
\hline M.W. & 5.2 & 15 \\
\hline S.P. & 5.1 & 13 \\
\hline J.P. & 4.11 & 15 \\
\hline L.S. & 5.0 & 16 \\
\hline $\mathrm{J} . \mathrm{M}$. & 6.0 & 14 \\
\hline A.T. & 6.1 & 13 \\
\hline M.L. & 6.1 & 14 \\
\hline E.C. & 6.1 & 15 \\
\hline K.M. & 6.1 & 14 \\
\hline T.W. & 6.0 & 16 \\
\hline D.P. & 6.1 & 16 \\
\hline C.G. & 6.1 & 14 \\
\hline T.M. & 6.1 & 14 \\
\hline K.P. & 6.0 & 15 \\
\hline T.B. & 6.11 & 16 \\
\hline S.F. & 7.1 & 16 \\
\hline J.S. & 6.10 & 16 \\
\hline M.S. & 6.10 & 16 \\
\hline M.H. & 6.10 & 15 \\
\hline E.L. & 6.10 & 15 \\
\hline S.S. & 7.0 & 16 \\
\hline M.D. & 7.1 & 16 \\
\hline D.S. & 7.1 & 13 \\
\hline N.P. & 6.11 & 16 \\
\hline S.H. & 7.10 & 15 \\
\hline T.W. & 8.1 & 15 \\
\hline M.K. & 7.11 & 13 \\
\hline K.S. & 8.2 & 15 \\
\hline C.H. & 8.0 & 15 \\
\hline J.B. & 7.11 & 16 \\
\hline $\mathrm{J} . \mathrm{B}$ & 8.1 & 16 \\
\hline J.M. & 8.0 & 16 \\
\hline C.J. & 7.11 & 16 \\
\hline M.M. & 8.0 & 16 \\
\hline
\end{tabular}

